\title{
Fine mapping of $A H I 1$ as a schizophrenia susceptibility gene: from association to evolutionary evidence
}

\author{
Federica Torri, ${ }^{*}{ }^{\dagger}$ Anna Akelai, ${ }^{*} *$ Sara Lupoli, ${ }^{\ddagger}$ Manuela Sironi, $\$$ \\ Daniela Amann-Zalcenstein, ${ }^{\ddagger \dagger}$ Matteo Fumagalli,, ,, Chiara Dal Fiume, ${ }^{*}$ Edna Ben-Asher, ${ }^{\dagger+}$ \\ Kyra Kanyas, ** Rachele Cagliani, $\$$ Paolo Cozzi, ${ }^{*}$ Gabriele Trombetti, ${ }^{*}$ \\ Luisa Strik Lievers, ${ }^{*}$, Erika Salvi, ${ }^{* \dagger}$ Alessandro Orro, ${ }^{\mathrm{I}, \#}$ Jacques S. Beckmann, ${ }^{\dagger+}$ \\ Doron Lancet, ${ }^{\ddagger \ddagger}$ Yoav Kohn, ${ }^{* *}$ Luciano Milanesi, ${ }^{\#}$ Richard B. Ebstein,,$\$$ \\ Bernard Lerer,** and Fabio Macciardi*, $* \|, 1$ \\ *Genomics and Bioinformatics Unit, University of Milan-Fondazione Filarete, and ${ }^{\dagger}$ Department of \\ Medicine, Surgery, and Dentistry, San Paolo Hospital, University of Milan, Milan, Italy; ${ }^{\ddagger}$ INSPE, \\ Scientific Institute San Raffaele, Milan, Italy; ${ }^{\S}$ Scientific Institute Istituto Di Ricovero e Cura a \\ Carattere Scientifico E. Medea, Parini, Italy; "Bioengineering Department, Politecnico di Milano, \\ Milan, Italy; ${ }^{\mathbb{\pi}}$ CILEA Consortium, Segrate, Milan, Italy; ${ }^{\#}$ Institute for Biomedical Technologies, \\ Consiglio Nazionale delle Ricerche, Milan, Italy; **Hadassah-Hebrew University Medical Center, \\ Jerusalem, Israel; ${ }^{\dagger \dagger}$ Centre Hospitalier Universitaire Vaudois and University of Lausanne, Lausanne, \\ Switzerland; ${ }^{\ddagger+}$ Weizmann Institute of Science, Rehovot, Israel; ${ }^{\S}$ Herzog Hospital, Jerusalem, Israel; and \\ ${ }^{\mathrm{II}}$ Department of Psychiatry and Human Behavior, University of California, Irvine, California, USA
}

ABSTRACT In previous studies, we identified a locus for schizophrenia on $6 q 23.3$ and proposed the Abelson helper integration site $1(A H I 1)$ as the candidate gene. $A H I 1$ is expressed in the brain and plays a key role in neurodevelopment, is involved in Joubert syndrome, and has been recently associated with autism. The neurodevelopmental role of $A H I 1$ fits with etiological hypotheses of schizophrenia. To definitively confirm our hypothesis, we searched for associations using a dense map of the region. Our strongest findings lay within the $A H I 1$ gene: single-nucleotide polymorphisms rs11154801 and rs7759971 showed significant associations $(P=6.23 \mathrm{E}-06 ; P=0.84 \mathrm{E}-06)$ and haplotypes gave $P$ values in the $10 \mathrm{E}-8$ to $10 \mathrm{E}-10$ range. The second highest significant region maps close to $A H I 1$ and includes the intergenic region between $B C 040979$ and $P D E 7 B$ (rs2038549 at $P=9.70 \mathrm{E}-06$ and rs1475069 at $P=6.97 \mathrm{E}-06$ ), and $P D E 7 B$ and $M A P 7$. Using a sample of Palestinian Arab families to confirm these findings, we found isolated signals. While these results did not retain their significance after correction for multiple testing, the joint analysis across the 2 samples supports the role of $A H I 1$, despite the presence of heterogeneity. Given the hypothesis of positive selection of schizophrenia genes, we resequenced a $11 \mathrm{~kb}$ region within $A H I 1$ in ethnically defined populations and found evidence for a selective sweep. Network analysis indicates 2 haplotype clades, with schizophrenia-susceptibility haplotypes clustering within the major clade. In conclusion, our data support the role of $A H I 1$ as a susceptibility gene for schizophrenia and confirm it has been subjected to positive selection, also shedding light on new possible candidate genes, MAP7 and PDE7B.Torri, F., Akelai, A., Lupoli, S., Sironi, M., AmannZalcenstein, D., Fumagalli, M., Dal Fiume, C., BenAsher, E., Kanyas, K., Cagliani, R., Cozzi, P., Trombetti, G., Lievers, L. S., Salvi, E., Orro, A., Beckmann, J. S.,
Lancet, D., Kohn, Y., Milanesi, L., Ebstein, R. B., Lerer, B., Macciardi, F. Fine mapping of $A H I 1$ as a schizophrenia susceptibility gene: from association to evolutionary evidence. FASEBJ. 24, 000-000 (2010). www.fasebj.org

Key Words: AHI1 association studies · positive selection

Schizophrenia IS A SEvere psychiatric disorder that has an important genetic component with heritability estimates around $\sim 80 \%$ (1) but no clearly defined mode of inheritance (2). Genetic epidemiological studies support a complex, "multifactorial," mode of transmission (3).

Family, twin, and adoption studies initially demonstrated the importance of this genetic component (4). Linkage studies subsequently implicated several chromosomal regions, but these were not fully replicated across different studies. Nevertheless, a certain covergence of positive linkage findings in specific chromosomal regions has emerged in different meta-analyses (5-7) and reviews $(8-10)$ : the most promising putative susceptibility genes are dysbindin $(D N T B 1)$, neuregulin 1 (NRG1), D-amino acid oxidase $(D A O)$, D-amino acid oxidase activator (DAOA; formerly known as G72), regulator of G-protein signaling 4 (RGS4), catechol- $O$ methyltransferase (COMT), and disrupted in schizophrenia 1 (DISC1).

To date, 10 genome-wide association studies of schizophrenia have been published (11-20): while evi-

\footnotetext{
${ }^{1}$ Correspondence: Dept. of Science \& Biomedical Technologies-School of Medicine, Università degli Studi di Milano, via F.lli Cervi, 93-20090 Segrate (Milano), Italy. E-mail: fabio.macciardi@unimi.it

doi: 10.1096/fj.09-152611
} 
dence has accumulated for several possible risk genes for schizophrenia (including some findings replicated across different large samples), specific susceptibility variants have yet to be discovered. The nature and degree of interactions and the specific risk conferred by each gene also remain to be characterized. Four recent genome wide copy number variants (CNVs) studies for the contribution of large $(>100 \mathrm{~kb}) \mathrm{CNVs}$ suggest that also rare (inherited or de novo) and highly penetrant structural variants may also be relevant to schizophrenia $(16,21-24)$, in particular CNVs that disrupt genes involved in brain development. However, the definitive contribution of common and rare CNVs to schizophrenia has not been clarified.

Intriguingly, several of the genes pinpointed by these studies are involved in brain development, in line with the neurodevelopmental model that has been a dominant explanatory theory for schizophrenia for more than 2 decades $(25,26)$.

The long arm of chromosome 6 stands among the most replicated and confirmed linkage findings ( 7 , 27-35), with the 6q15-23.2 locus suggested as a strong schizophrenia candidate region (7). The same region seems also to be involved in bipolar disorder (7, 36-38). In a previous genome-wide linkage analysis, we first reported strong evidence for a positive finding on chromosome 6q23.3 (39) and then (40) further refined the confidence linkage interval from 126.0 to $146.0 \mathrm{Mb}$, with the peak at $136.3 \mathrm{Mb}$. This region was then analyzed using 180 single-nucleotide polymorphisms (SNPs) within and flanking 20 putative candidate genes expressed in brain and potentially relevant for the pathophysiology of schizophrenia (41). The 7 significantly overtransmitted alleles were then replicated by an independent Icelandic case control study (42). Our data led to the identification of a $\sim 500-\mathrm{kb}$ genomic region significantly associated with schizophrenia even after correction for multiple testing.

This region harbors the Abelson helper integration site 1 gene (AHI1) and BC040979 (previously known as C6orf217), an adjacent primate-specific gene currently identified as hypothalamic mRNA. The upstream region may contain regulatory elements for $A H I 1$ and also for the distally located $P D E 7 B$ gene. $A H I 1$ is expressed in brain (43), and its role in neurodevelopment is suggested by its involvement not only in schizophrenia but also in Joubert syndrome (gene mutation; ref. 44) and autism (association study, 45). Interestingly, these 2 diseases often share behavioral traits (46). Schizophrenia and autism, both psychoses, are now independent diseases in the Diagnostic and Statistical Manual of Mental Disorders, Fourth Edition (DSM-IV; ref. 47), but intriguingly the term "autism" was first used by Bleuler (48) to describe some of the schizophrenic features.

Our main aim was to unequivocally confirm $A H I 1$ as a susceptibility gene for schizophrenia by performing a dense and fine linkage disequilibrium (LD) mapping involving 2019 SNPs in the same Arab-Israeli sample that allowed the initial identification of the region. We also fine-genotyped a different sample of Arab families (129 nuclear families) with 1375 SNPs in the same $\sim 9-\mathrm{Mb}$ interval. Our second goal was to confirm whether $A H I 1$ has been subjected to natural selection in humans given the previously reported evidence that a portion of genes putatively related to schizophrenia (49) may be fast evolving and the recent suggestion of AHI1 as a target of positive selection $(50,51)$.

\section{MATERIALS AND METHODS}

\section{Family samples and diagnostic methods}

We studied 2 different samples of Arab origin, the TKT and BT samples (39-41). The index family-based association sample for this study (TKT) was slightly enlarged from previous work (41) and consisted of 58 nuclear families of Arab-Israeli origin including a total of 198 individuals, 99 of which are affected (89 probands and 10 parents; Table $\mathbf{1}$ ). We did not have the DNA of 16 individuals. The sample is drawn from an ethnically homogenous population that originated $<30$ generations ago with a limited number of founders and that shows a high birth rate, an unusually high level of consanguinity, and a low rate of intermarriage with other population groups in Israel $(52,53)$. Thirty-six are trio families (affected proband with both parents), while 22 have multiple affected offspring (11 with 2, 6 with 3, 2 with 4, and 3 with 5-7). To establish psychiatric diagnosis, TKT subjects were interviewed with the Schedule for Affective Disorders and Schizophrenia-Lifetime Version (SADS-L; ref. 54) and were questioned about psychiatric symptoms in the family according to the Family History Research Diagnostic Criteria (FH-RDC; ref. 55). Medical records of hospitalizations and clinic care were obtained for affected individuals. The completed SADS-L interview form, FH-RDC information, and medical records were reviewed by 2 experienced members of the research team and, in cases where consensus was not achieved, by the principal investigator (B.L.). Lifetime diagnoses were established according to the Research Diagnostic Criteria (RDC; ref. 54) and the DSM-IV (47) using a best estimate consensus procedure (56). All diagnostic evaluations were completed without knowledge of the genotyping data. A broad diagnostic category was employed, and this encompassed 79 subjects with schizophrenia, 17 with schizoaffective disorder, and 3 with unspecified functional psychosis (RDC; ref. 54).

The BT sample is also of Arab origin but is outbred and was recruited from different geographical regions of Israel and the Palestinian Authority. The sample consisted of $129 \mathrm{nu}-$ clear families with a total of 421 individuals, 165 of whom are affected (165 probands, no affected parents). The sample is made up of 105 trio families and 24 families with multiple affected offspring (18 with 2, 2 with 3, 2 with 4, and 2 with 5). For the BT sample, the affected individuals were diagnosed with schizophrenia according to DSM-IV (47) on the basis of interview with the Structured Clinical Interview for DSM-IV Axis I Disorders (SCID; ref. 57). All BT subject were diagnosed with schizophrenia. We evaluated the reliability of diagnoses across the 2 samples by independent assessment, as

TABLE 1. Description of the BT and TKT samples and the number of SNPs genotyped across the 2 datasets

\begin{tabular}{lccc}
\hline \hline Sample & $\begin{array}{c}\text { Nuclear } \\
\text { families }(n)\end{array}$ & Probands $(n)$ & $\begin{array}{c}\text { Genotyped } \\
\text { SNPs }(n)\end{array}$ \\
\hline TKT & 58 & 89 & 2019 \\
BT & 129 & 165 & 1375 \\
\hline
\end{tabular}


detailed in Amann-Zalcenstein et al. (41; also see Supplemental Material).

The project was approved by the Hadassah-Hebrew University Medical Centre Helsinki Committee (Internal Review Board), and informed consent for inclusion in this study was given by all the subjects.

\section{Genotyping}

Genomic DNA was extracted using standard methods. Genotyping was performed at the University of Milan, using 2 complementary DNA microarray approaches $(58,59)$. For the TKT sample, we performed a whole-genome scan with the humancnv370 chip (Illumina, San Diego, CA, USA) assaying 370,404 SNPs, among which 1183 mapped within the 131.32140.24 linkage region in 6q23-24 reported by Amann-Zalcenstein et al. (41). We increased the map density in this region with 836 additional SNPs using a custom SNP array, the Golden Gate Genotyping Assay (Illumina). In total, we genotyped 2019 SNPs within the identified linkage region (131.32-140.24 Mb). To select the SNPs to be genotyped with the custom array, we identified the best tagging SNPs within the 131.32-140.24 region in 6q23-24, in addition to those present on humancnv370 array.

Among all SNPs, 88 had been genotyped in the previously reported study of Amann-Zalcenstein et al. (41; for the complete list see Supplemental Table S2). The average intermarker distance is $\sim 4.9 \mathrm{~kb}$, with the smallest and the largest gaps being 14 and $43.2 \mathrm{~kb}$, respectively. In this way, we reached a 3.5 -fold greater coverage than the previously performed studies in the $1-\mathrm{Mb}$ area around the linkage peak that in Amann-Zalcenstein et al. (41) showed the highest SNP density and a 13.6-fold greater coverage for the remaining region.

We also genotyped the BT sample with 1375 SNPs, selected as the most informative from the panel of 2019 markers of the TKT sample and mapping in the same linkage interval (131.32-140.24 Mb) using again a Golden Gate Genotyping Assay. In both the TKT and BT samples, the AHI1 gene was densely covered (by 27 and 22 informative SNPs, respectively).

Normalized bead intensity data obtained for each sample were analyzed with the Illumina Genome Studio v1.0.2 software, which generated SNP genotypes from fluorescent intensities using the manufacturer's default cluster settings. Quality controls included evaluation of call rate; check of SNPs with 1) no calls, 2) with a minor allele frequency $(\mathrm{MAF})<0.05$, and 3) with a genotyping rate $<0.9$. SNPs that did not match these criteria were removed from further analyses. Also, individuals with missing genotyping $>10 \%$ were not included in the analyses. An additional quality control step was performed to exclude individuals and/or markers based on Mendelian error rate (PLINK 1.04; ref, 60; http://pngu.mgh.harvard.edu/ purcell/plink/). SNPs with $>10 \%$ and families with $>5 \%$ Mendelian errors were discarded. In addition, SNPs that showed a significant deviation from Hardy-Weinberg Equilibrium (HWE; $P<0.00001$ ) were flagged for evaluation before excluding them from further analyses. In particular, we specifically checked whether SNPs mapping to the AHI1 locus significantly deviated from $\mathrm{HWE}$ equilibrium $(P<0.00001)$ in parents or in affected offspring, given the different meaning of deviation from HWE in "normal" compared with "affected" subjects (61-63).

We used Haploview 4.00 (ref. 64; http://www.broad.mit. $\mathrm{edu} / \mathrm{mpg} /$ haploview/) to calculate intermarker LD between all SNP pairs within a $1-\mathrm{Mb}$ interval and to generate a graphical view of the LD pattern across the entire genomic region. Haplotype blocks were defined using the 4-gamete rule algorithm (65).

Genetic power calculation were performed with the Genetic Power Calculator tool (ref. 66; http://pngu.mgh.harvard. $\mathrm{edu} / \sim$ purcell/gpc/).

\section{Association analyses}

We used PBAT 3.6 (refs. 67, 68; http://www.biostat.harvard. edu/), which incorporates an extended and improved transmission disequilibrium test (TDT; ref. 69), to perform association analyses under the null hypothesis of "previous linkage and no association" with the sandwich option (sw) for robust estimation of the variance, conditioning on traits and parental genotypes. Following the same strategy as AmannZalcenstein et al. (41), we also performed a 3-SNP "slidingwindow" haplotype analysis as implemented in PBAT. Haplotype analysis was restricted to adjacent SNPs and was performed using the additive model, given that schizophrenia follows a complex mode of inheritance. The minimal number of informative families was set to 10 , and the minimal haplotype cutoff frequency was set to 0.05 . Correction for multiple testing was performed using the $q_{\mathrm{FDR}}$ value, which is an extension of the false discovery rate (FDR) method (70). The $q$ values were calculated with the QVALUE R package using the smoother method (71).

The Search Tool for the Retrieval of Interacting Genes/ Proteins (STRING; ref. 72) was used to find protein interaction information. SNP annotation was based on the most recent version of both GenomeBuild (Build36.3) and dbSNP (release 129). The networks shown were generated through the use of the Ingenuity Pathways Analysis classification system (Ingenuity Systems, Redwood City, CA, USA; http:// www.ingenuity.com).

\section{Joint-analyses of BT and TKT association results}

We performed a joint analysis between TKT and BT sample association results for the SNPs (Table 2) and the haplotype windows mapping in and/or near AHI1 showing the best association $P$ values in the TKT sample. An overall odds ratio (OR) and 95\% confidence interval was estimated under the Mantel-Haenszel's fixed effects model (73) using a METAN routine implemented in STATA. The number of each transmitted allele from heterozygous parents to affected offspring was treated as the number of occurrences of that "risk" or "norisk" allele in cases. The controls were assumed from a very large population with equal numbers of each allele (to reflect

TABLE 2. Original and surrogate alleles tested for association in TKT and BT populations

\begin{tabular}{llrlr}
\hline \hline & \multicolumn{3}{c}{ Marker } \\
\cline { 2 - 5 } Sample & rs7759971-C & rs11554801-C & rs1475069-A & rs2038549-G \\
\hline TKT & $\begin{aligned} \text { rs7759971-C } \\
\text { BT }\end{aligned}$ & $\begin{array}{r}\text { rs11554801-C } \\
\text { rs96473695-A }\end{array}$ & $\begin{array}{l}\text { rs1475069-A } \\
\text { rs1475069-A }\end{array}$ & $\begin{array}{r}\text { rs2038549-G } \\
\text { rs2038549-G }\end{array}$ \\
\hline
\end{tabular}


the expected 50:50 transmission ratio from parents to offspring (74).

\section{Evolutionary analysis of AHI1}

DNA samples and sequencing

Human genomic DNA was obtained from the Coriell Institute for Medical Research (Camden, NJ, USA). All analyzed regions were PCR amplified and directly sequenced (primer sequences are available on request). PCR products were treated with ExoSAP-IT (USB Corporation, Cleveland, OH, USA), directly sequenced on both strands with a Big Dye Terminator Sequencing Kit (v3.1 Applied Biosystems, Foster City, CA, USA) and run on an Applied Biosystems ABI 3130 XL Genetic Analyzer. Sequences were assembled using AutoAssembler version 1.4.0 (Applied Biosystems) and inspected manually by 2 distinct operators. Genomic coordinates [National Center for Biotechnology Information (NCBI) Build 36.1] for the resequenced region are chr6: 135713023-135724493.

\section{Data retrieval and haplotype construction}

Genotype data for 238 resequenced human genes were derived from the National Institute of Environmental Health Sciences (NIEHS) SNP program web site (http://egp.gs. washington.edu/). Haplotypes were inferred using PHASE $2.1(75,76)$, a program for reconstructing haplotypes from unrelated genotype data through a Bayesian statistical method.

\section{Statistical analysis}

Tajima's $D(77), \mathrm{Fu}$ and Li's $D^{*}$ and $F^{*}(78)$ statistics, as well as diversity parameters $\theta_{\mathrm{W}}(79)$ and $\pi(80)$ and Fay and Wu's $H(81)$ were calculated using libsequence (82). Calibrated coalescent simulations were performed using the "cosi" package (83) and its best-fit parameters for YRI and EA with 10,000 iterations. The Ewens-Watterson homozygosity test (79) was performed using Arlequin (84). The maximumlikelihood-ratio HKA test was performed using the maximumlikelihood-ratio HKA (MLHKA) software (85) using multilocus data from 16 NIEHS genes, as described previously (86). Median-joining networks to infer haplotype genealogy were constructed using Network 4.5 (87).

\section{RESULTS}

\section{Summary statistics}

We genotyped a $\sim 9-\mathrm{Mb}$ linkage interval on chromosome $6 \mathrm{q}$, starting at $131.32 \mathrm{Mb}$ and ending at 140.24 $\mathrm{Mb}$ (genome Build36.3), using 2019 SNPs in the TKT sample and 1375 in the BT sample. This region harbors 58 known genes (including 1 known miRNA, hsa-mir$548 \mathrm{a}-2), 43$ of which are mapped by $\geq 1$ of the genotyped SNPs. Of these 2019 SNPs, 88 were included in our previous study (41; for a complete list see Supplemental Table S2). Four of those 88 common SNPs had inconsistent genotypes with our previous report (41) and were thus removed (see Supplemental Table S3).

We verified that the positions of the 88 genotyped SNPs did not vary between the build (Build 36.3) used for the SNP annotation with that used by AmannZalcenstein et al. (41). In the current dbSNP129 release, 8 of the 2019 SNPs are not present, but none of them maps in the AHI1 region of interest (see Supplemental Table S1). Quality control procedures and results are summarized in Supplemental Table S4. Our sample is powered enough to detect a significant association with a TDT design (66).

\section{LD structure and single-SNP association analysis}

Within the genotyped $~ 9-\mathrm{Mb}$ interval, we identified in the TKT sample a region (135.6-136.9 Mb) showing a highly conserved LD structure as also present in reference HapMap populations (Fig. 1). This region includes the $A H I 1$, $P D E 7 B$, and $M A P 7$ genes, each covered by well-defined LD blocks (Fig. 1 and Supplemental Material). Our best association findings fall exactly within this region (Fig. 2, red arrow).

Table 3 and Fig. 2 show the results of the best single SNP association analysis (see Supplemental Table S6 for the complete list of all the $P$ and $q_{\text {FDR }}$ values for all SNPs in the entire region).

Among the 68 SNPs genotyped in this area, 53 show a nominal significant $P$ value, and 33 are still significant after FDR correction (Table 3). The strongest associated SNPs are the same as those previously reported by AmannZalcenstein et al. (41), namely rs11154801 ( $P=6.23 \mathrm{E}-06$; $\left.q_{\mathrm{FDR}}=1.09 \mathrm{E}-04\right)$ and $\mathrm{rs} 7759971\left(P=1.84 \mathrm{E}-06 ; q_{\mathrm{FDR}}=8.61 \mathrm{E}-\right.$ $05)$. They are included in a region of $\sim 500 \mathrm{~kb}(135.6-$ $136.1 \mathrm{Mb}$ ) encompassing the AHI1 and BC040979 genes, as indicated by a red arrow in Fig. 2. These 2 genes map very close to each other, within a 61-bp interval, and lie in a very high $\mathrm{LD}$ region that extends downstream the $5^{\prime}$ of $A H I 1$ (here downstream means at the $3^{\prime}$ of AHI1, so toward the telomere) distally. Here we found 2 additional significant SNPs, rs2038549 $\left(P=9.70 \mathrm{E}-06 ; q_{\mathrm{FDR}}=2.77 \mathrm{E}-003\right)$ and $\mathrm{rs} 1475069(P=6.97 \mathrm{E}-$ $\left.06 ; q_{\mathrm{FDR}}=2.39 \mathrm{E}-03\right)$. This region may contain sequences possibly having a regulatory role for both $A H I 1$ and $P D E 7 B$ given that the 2 genes are transcribed in opposite direction. Across the entire 9-Mb genotyped region, no other SNP shows association with a $P$ value $<10 \mathrm{E}-5$, but there are several SNPs with $P$ values ranging from $10 \mathrm{E}-3$ to 10E-4 (Supplemental Table S6).

For the BT population, only $3 \mathrm{SNPs}$ reach $P$ values of 10E-04, none of which survives FDR correction (rs6929048: $P=7.59 \mathrm{E}-04, q_{\mathrm{FDR}}=0.370174 ; \mathrm{rs} 1414980: P=8.03 \mathrm{E}-04$, $q_{\mathrm{FDR}}=0.370174$ in EYA4 gene; rs6570251: $P=8.22 \mathrm{E}-04$, $q_{\text {FDR }}=0.370174$; see Supplemental Table S7 and Supplemental Fig. S1). Single SNP association results for the AHI1-BC040979-PDE7B-MAP7 locus in BT sample are summarized in Supplemental Table S8.

A joint analysis for our most significantly associated SNPs (rs7759971 and rs11154801 within AHI1 and intergenic SNPs rs2038549 and rs1475069) in the TKT and BT samples shows significant heterogeneity across the 2 samples (MH-het $P$ values from 0.002 to 0.035 ; Table 4). The ORs for associations have values ranging from 1.2 to 1.88 similar to other SNPs found associated to schizophrenia in other published papers [see for example Allen et al. (10) and other studies in the Introduction]. 

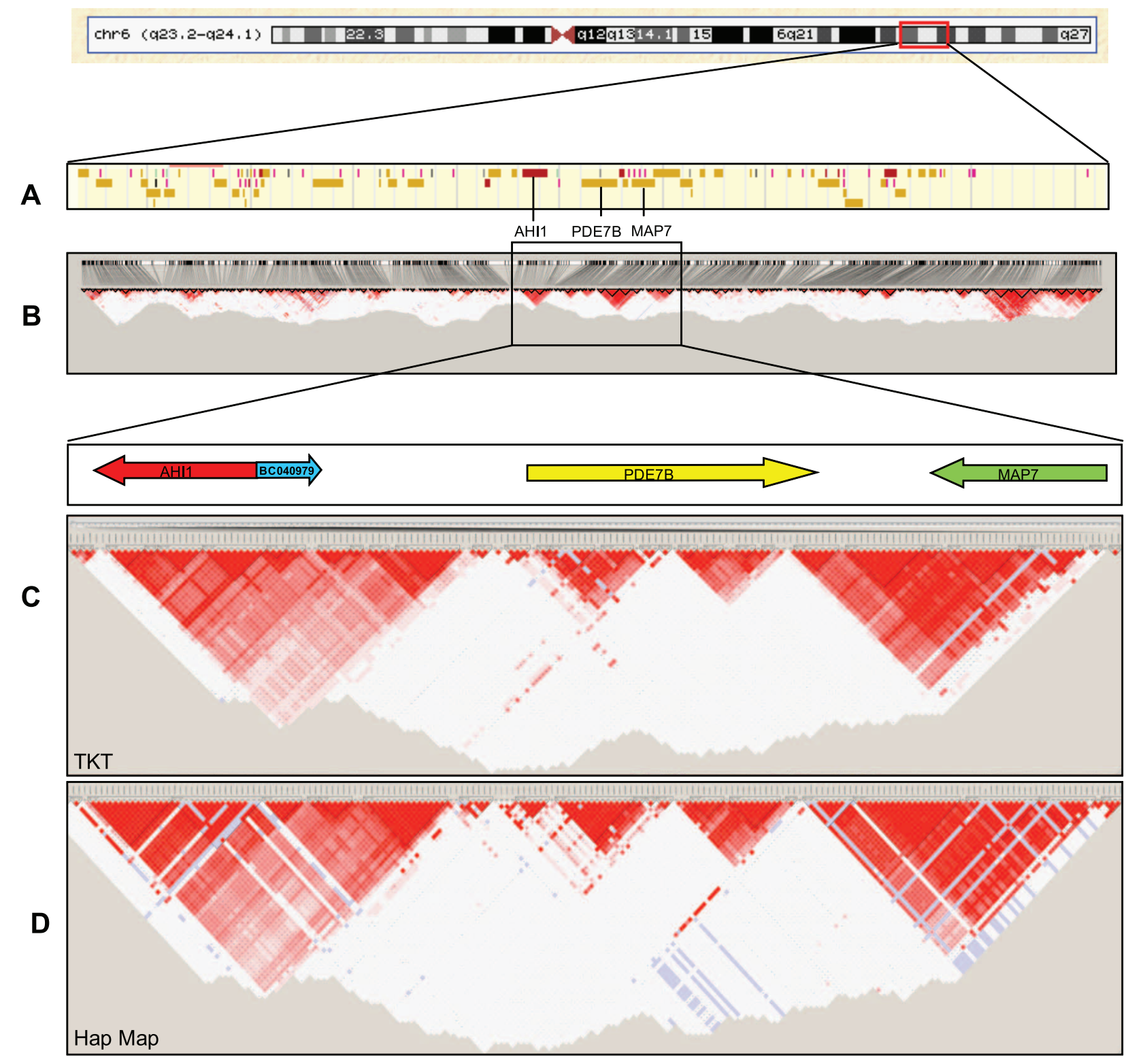

Figure 1. Genomic region on chromosome 6q23 for fine mapping of a schizophrenia susceptibility locus in an Arab-Israeli sample. A) Distribution of known genes spanning a $\sim 9$-Mb genomic region underneath a previously shown linkage peak for schizophrenia in the same Arab-Israeli sample. $B$ ) General overview of the haplotype blocks detected with Haploview software. Black rectangle contains the haplotype blocks mapping in the region encompassing the AHI1, BC040979, PDE7B, and MAP7 genes. $C, D)$ Zoomed views of boxed area in $B$ for TKT sample $(C)$ and HapMap subjects $(D)$.

The second most significant genic region in TKT sample includes the $P D E 7 B$ and $M A P 7$ genes. Of 106 SNPs, 22 yielded values of $P<0.05$, the most significant being rs2142921 $\left(P=2.20 \mathrm{E}-03 ; q_{\mathrm{FDR}}=9.46 \mathrm{E}-02\right)$ and rs9376173 $\left(P=6.41 \mathrm{E}-03 ; q_{\mathrm{FDR}}=9.96 \mathrm{E}-01\right)$, but none of these survived FDR correction (see Supplemental Table S5). Figure 3 summarizes these results, also showing the transcription polarity of the genes.

Across AHI1, BC040979, PDE7B, and MAP7 genes, we observed deviation from HWE for 15 SNPs in affected individuals only. Three of these SNPs map in the AHII gene (rs2614276, rs11154801, and rs12206850) and 4 in BC040979 (rs10484771, rs4896156, rs2143681, and rs3734213). In both cases, these SNPs are also signifi- cantly associated to schizophrenia. For the remaining 9 SNPs, 8 map in the intergenic region between $B C 040979$ and $P D E 7 B$.

\section{Haplotype association analyses}

To improve the informativeness of single SNP association analysis, we performed a 3-SNP sliding-window haplotype analysis. In the TKT sample, we detected a total of 6137 individual haplotypes (Supplemental Table S11), and we corrected with the FDR procedure (70). In the AHI1-PDE7B-MAP7 region (Fig. 4A), we detected a total of 576 individual haplotypes (Supple- 


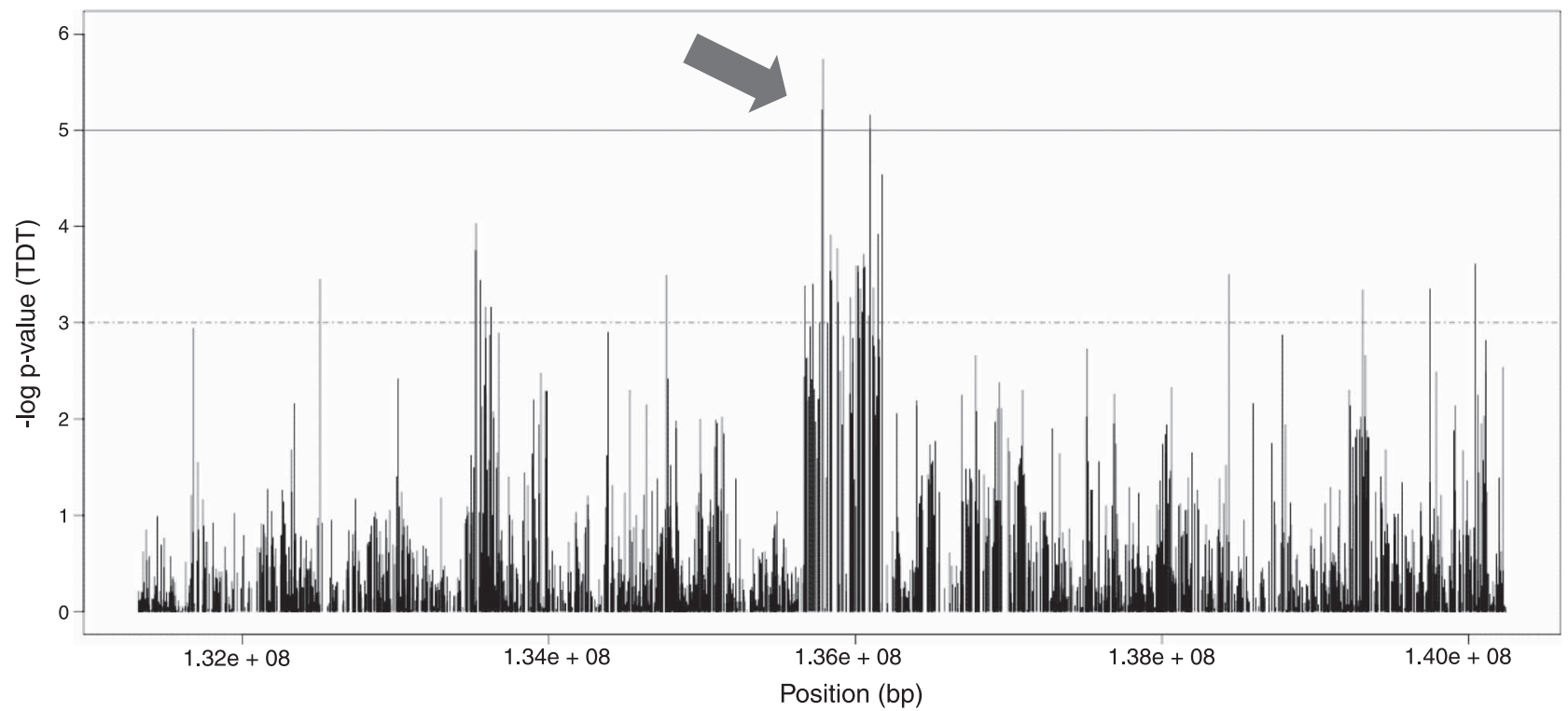

Figure 2. Plot of $-\log 10 P$ values for TDT association test across the $\sim 9-\mathrm{Mb}$ linkage region to schizophrenia on chromosome $6 q 23.3$ (131.32-140.24 Mb). Reference red lines indicate thresholds for significance (solid line, $P=10 \mathrm{E}-5$; dashed line, $P=10 \mathrm{E}-3)$. Arrow indicates best association findings within the AHI1 locus.

mental Table S9). We found an outstanding haplotype association signal with $P=10 \mathrm{E}-10$ within $A H I 1$ with haplotype windows encompassing SNPs in very high LD with rs1154801, the top associated SNP, and with rs9321501, which was contained in the most significantly associated haplotype windows in the previous Amann-Zalcenstein et al. (41) work (Fig. $4 B$ and Table 4). These haplotype windows did not display any significant association to schizophrenia in the BT sample (Supplemental Table S10 and full results in Supplemental Table S12). The joint analysis with BT haplotype association analyses for these TKT best 2 windows displayed combined ORs of $\sim 1.3$, again strengthening the significance of this association signal given also the extremely higher weight of BT sample on the analysis.

\section{Evolutionary analysis of $A H I 1$}

Previous analyses of human/primate divergence indicated that the $5^{\prime}$ region of the human AHII has undergone directional selection (43). Also, a genomewide search (50) for genes subjected to recent positive selection based on extreme $F_{\mathrm{ST}}$ values indicated both $A H I 1$ and PDE7B as possible candidates. We therefore analyzed the $F_{\mathrm{ST}}$ profile of an extended genomic region containing AHII and PDE7B. Using HapMap data for Europeans $(\mathrm{CEU})$ and Yoruba (YRI), we calculated $F_{\mathrm{ST}}$ values in 60-SNP sliding windows across a $5-\mathrm{Mb}$ region centered around the AHI1-MAP7 genomic interval. SNPs with a MAF $<0.05$ (averaged over the 2 populations) were not considered for $F_{\mathrm{ST}}$ calculation. As shown in Fig. 5, the region extending from AHI1 to $M A P 7$ displays relatively high population differentiation; 1 major $F_{\mathrm{ST}}$ peak corresponds to the terminal portion of AHI1, while a second extended region with high population differentiation extends into PDE7B. As reported above, high $F_{\mathrm{ST}}$ levels are regarded as an indication of positive selection (reviewed in ref. 88). Another expectation under a positive selection regime is an excess of high-frequency derived alleles. Again, HapMap data suggested positive selection (Fig. 5). Resequencing of target regions is considered the most reliable approach for investigating the evolutionary history of a genomic region since it allows identification of all variants in an unbiased way (89).

In a recent study, Yu et al. (51) resequenced 2 regions of AHI1 covering exons 5-12 and 15-17. By applying a empirical comparison with random genomic regions, they indicated that the gene has been subjected to positive selection. Here we sequenced $11 \mathrm{~kb}$ in AHII in 40 HapMap subjects (20 CEU and $20 \mathrm{YRI}$ ). In particular, we selected a region covering rs2614276, one of the most strongly associated SNPs in our sample, and rs17707754, which is involved in susceptibility to autism (45). This region is located downstream exon 17 and includes exon 24.

Nucleotide diversity was assessed using 2 indexes: $\theta_{\mathrm{W}}$ (90), an estimate of the expected per site heterozygosity, and $\pi(80)$, the average number of pairwise sequence nucleotide differences. To compare the values obtained for the $A H I 1$ gene region, we calculated $\theta_{\mathrm{W}}$ and $\pi$ for 238 genes resequenced by the NIEHS program in CEU and YRI; the percentile rank in the distribution of NIEHS gene values is reported in Table $\mathbf{5}$ and indicates that the AHI gene region displays low nucleotide diversity in CEU.

Application of commonly used neutrality tests such as Tajima's $D\left(D_{\mathrm{T}}\right.$; ref. 77$)$, Fu and Li's $D^{*}$ and $F^{*}(78)$, as well as Fay and Wu's $H(81)$ did not allow rejection of the null neutral model for the AHI1 genomic region in either CEU or YRI (Table 5). Conversely, the EwensWatterson homozygosity test (79) gave a nearly significant result (Table 5) in CEU. Under neutral evolution, the amount of within-species diversity is predicted to correlate with levels of between-species divergence, since both depend on the neutral mutation rate. The 
TABLE 3. Single SNP association result for the $\sim 500 \mathrm{~kb}(135.6-136.1 \mathrm{Mb})$ with the strongest association signal in our scan

\begin{tabular}{|c|c|c|c|c|c|c|c|}
\hline rs1052502 & 135648258 & AHI1 & - & $\mathrm{T}$ & C & $3.58 \mathrm{E}-01$ & - \\
\hline rs7766656 & 135659294 & AHI1 & - & $\mathrm{G}$ & A & $5.07 \mathrm{E}-01$ & - \\
\hline rs6931735 & 135666504 & AHII & - & $\mathrm{G}$ & $\mathrm{A}$ & $3.60 \mathrm{E}-03$ & - \\
\hline rs6912933 & 135669227 & AHII & - & G & A & $4.16 \mathrm{E}-04$ & 2.33E-02 \\
\hline rs4896143 & 135676793 & AHI1 & - & G & $\mathrm{C}$ & $5.47 \mathrm{E}-03$ & - \\
\hline rs2064430 & 135684449 & AHI1 & - & $\mathrm{T}$ & $\mathrm{C}$ & $2.31 \mathrm{E}-03$ & - \\
\hline rs9321502 & 135697945 & AHI1 & - & $\mathrm{C}$ & $\mathrm{A}$ & $5.88 \mathrm{E}-03$ & - \\
\hline rs2244745 & 135704514 & AHII & - & $\mathrm{T}$ & A & $1.10 \mathrm{E}-03$ & 3.93E-02 \\
\hline rs2746430 & 135714985 & AHII & - & $\mathrm{A}$ & $\mathrm{T}$ & $3.92 \mathrm{E}-03$ & $8.20 \mathrm{E}-02$ \\
\hline rs2614276 & 135723397 & AHII & 0.0260 & $\mathrm{~T}$ & $\mathrm{C}$ & $3.96 \mathrm{E}-04$ & 2.33E-02 \\
\hline rs2246943 & 135733209 & AHII & - & A & $\mathrm{T}$ & $4.95 \mathrm{E}-03$ & - \\
\hline rs2757649 & 135768306 & AHI1 & - & $\mathrm{C}$ & $\mathrm{A}$ & $9.97 \mathrm{E}-04$ & $3.76 \mathrm{E}-02$ \\
\hline rs11154801 & 135781048 & AHII & 0.0359 & A & $\mathrm{C}$ & $6.23 \mathrm{E}-06$ & $2.39 \mathrm{E}-03$ \\
\hline rs7759971 & 135788577 & AHI1 & & $\mathrm{T}$ & $\mathrm{C}$ & $1.84 \mathrm{E}-06$ & $1.58 \mathrm{E}-03$ \\
\hline rs1535435 & 135798715 & AHI1 & - & $\mathrm{A}$ & $\mathrm{G}$ & $9.32 \mathrm{E}-01$ & - \\
\hline rs717120 & 135806822 & AHI1 & - & $\mathrm{C}$ & $\mathrm{T}$ & $4.04 \mathrm{E}-02$ & - \\
\hline rs2614267 & 135818171 & AHI1 & - & $\mathrm{A}$ & $\mathrm{T}$ & $9.96 \mathrm{E}-04$ & $3.76 \mathrm{E}-02$ \\
\hline rs6908428 & 135835399 & AHI1 & - & G & $\mathrm{A}$ & 2.93E-04 & $2.30 \mathrm{E}-02$ \\
\hline rs 12206850 & 135839501 & AHI1 & 0.0317 & $\mathrm{C}$ & $\mathrm{T}$ & $1.23 \mathrm{E}-04$ & $2.10 \mathrm{E}-02$ \\
\hline rs 4526212 & 135846324 & AHI1 & - & $\mathrm{A}$ & $\mathrm{C}$ & $3.59 \mathrm{E}-04$ & 2.30E-02 \\
\hline rs9647635 & 135882749 & BC040979 & - & C & $\mathrm{A}$ & $1.72 \mathrm{E}-04$ & $2.29 \mathrm{E}-02$ \\
\hline rs9399148 & 135886052 & BC040979 & - & $\mathrm{T}$ & $\mathrm{A}$ & $6.11 \mathrm{E}-04$ & $2.69 \mathrm{E}-02$ \\
\hline rs9389295 & 135889916 & BC040979 & - & C & $\mathrm{T}$ & $3.17 \mathrm{E}-03$ & - \\
\hline rs4896156 & 135968556 & BC040979 & 0.0122 & $\mathrm{G}$ & $\mathrm{A}$ & $5.55 \mathrm{E}-04$ & $2.50 \mathrm{E}-02$ \\
\hline rs2143681 & 135974698 & BC040979 & - & A & G & $8.63 \mathrm{E}-03$ & - \\
\hline rs719885 & 135981048 & BC040979 & - & G & $\mathrm{A}$ & $2.57 \mathrm{E}-03$ & - \\
\hline rs3734213 & 135983001 & BC040979 & 0.0087 & $\mathrm{C}$ & $\mathrm{T}$ & $1.44 \mathrm{E}-03$ & $4.20 \mathrm{E}-02$ \\
\hline rs7761716 & 135986074 & BC040979 & - & $\mathrm{G}$ & $\mathrm{A}$ & 2.07E-02 & - \\
\hline rs9402729 & 135993702 & BC040979 & - & $\mathrm{A}$ & $\mathrm{G}$ & $4.30 \mathrm{E}-02$ & - \\
\hline rs9494311 & 136003712 & BC040979 & - & $\mathrm{C}$ & $\mathrm{T}$ & $8.16 \mathrm{E}-02$ & - \\
\hline rs9483858 & 136005501 & BC040979 & - & G & $\mathrm{A}$ & $2.55 \mathrm{E}-04$ & 2.30E-02 \\
\hline rs10782258 & 136017953 & BC040979 & - & $\mathrm{A}$ & $\mathrm{T}$ & $3.04 \mathrm{E}-04$ & $2.30 \mathrm{E}-02$ \\
\hline rs6917005 & 136019673 & BC040979 & - & G & A & $2.55 \mathrm{E}-04$ & $2.30 \mathrm{E}-02$ \\
\hline rs9321520 & 136027787 & BC040979 & - & $\mathrm{T}$ & $\mathrm{C}$ & $1.46 \mathrm{E}-03$ & 4.20E-02 \\
\hline rs9321521 & 136031343 & BC040979 & - & $\mathrm{A}$ & G & $4.44 \mathrm{E}-04$ & $2.33 \mathrm{E}-02$ \\
\hline rs10223338 & 136043720 & BC040979 & - & $\mathrm{T}$ & $\mathrm{C}$ & $7.84 \mathrm{E}-04$ & $3.20 \mathrm{E}-02$ \\
\hline rs9494332 & 136050301 & BC040979 & - & $\mathrm{G}$ & $\mathrm{A}$ & $2.74 \mathrm{E}-04$ & 2.30E-02 \\
\hline rs9389318 & 136055227 & & - & C & $\mathrm{T}$ & $1.96 \mathrm{E}-04$ & $2.29 \mathrm{E}-02$ \\
\hline rs 12202212 & 136060840 & & - & $\mathrm{T}$ & $\mathrm{C}$ & $2.63 \mathrm{E}-04$ & $2.30 \mathrm{E}-02$ \\
\hline rs9321528 & 136084366 & & - & G & $\mathrm{C}$ & $8.46 \mathrm{E}-04$ & $3.37 \mathrm{E}-02$ \\
\hline rs2038549 & 136094641 & & - & A & G & $9.70 \mathrm{E}-06$ & $2.77 \mathrm{E}-03$ \\
\hline rs1475069 & 136097927 & & - & C & $\mathrm{A}$ & $6.97 \mathrm{E}-06$ & $2.39 \mathrm{E}-03$ \\
\hline rs1033755 & 136112384 & & 0.0140 & A & G & $1.37 \mathrm{E}-03$ & $4.20 \mathrm{E}-02$ \\
\hline rs2208574 & 136117310 & & 0.0021 & A & G & $4.36 \mathrm{E}-04$ & $2.33 \mathrm{E}-02$ \\
\hline rs9399161 & 136122157 & & - & $\mathrm{G}$ & A & $1.72 \mathrm{E}-03$ & $4.76 \mathrm{E}-02$ \\
\hline rs2104132 & 136126641 & & - & $\mathrm{T}$ & A & $2.23 \mathrm{E}-03$ & - \\
\hline rs9399164 & 136128239 & & - & $\mathrm{T}$ & G & $9.21 \mathrm{E}-03$ & - \\
\hline
\end{tabular}


TABLE 3. (continued)

\begin{tabular}{|c|c|c|c|c|c|c|c|}
\hline rs9483880 & 136144305 & & 0.0071 & $\mathrm{G}$ & $\mathrm{C}$ & $1.03 \mathrm{E}-02$ & - \\
\hline rs981580 & 136149323 & & 0.0328 & $\mathrm{G}$ & $\mathrm{A}$ & $1.20 \mathrm{E}-04$ & 2.10E-02 \\
\hline rs9399167 & 136155509 & & 0.0326 & C & $\mathrm{T}$ & $4.21 \mathrm{E}-03$ & - \\
\hline rs6925090 & 136158170 & & 0.0326 & $\mathrm{C}$ & $\mathrm{T}$ & $2.28 \mathrm{E}-03$ & - \\
\hline rs 1885275 & 136160513 & & - & A & A & $8.10 \mathrm{E}-01$ & - \\
\hline rs 1342236 & 136206493 & & - & A & A & $9.45 \mathrm{E}-01$ & - \\
\hline rs6570047 & 136210916 & & - & $\mathrm{C}$ & $\mathrm{A}$ & $8.28 \mathrm{E}-01$ & - \\
\hline
\end{tabular}

Only values of HW $P<0.05$ and $q<0.05$ are reported.

HKA test (91) is commonly used to verify whether this expectation is verified. Here we applied an MLHKA test (85) by comparing polymorphisms and divergence levels at the $A H I 1$ genomic region with 16 NIEHS genes resequenced in CEU and YRI (see Materials and Methods). The results are shown in Table $\mathbf{6}$ and indicate that a significant reduction in nucleotide diversity $v s$. divergence is detectable in the CEU sample. These data, together with the high $F_{\mathrm{ST}}$ values observed in the region (ref. 50 and Fig. 5), confirm the previous suggestion (51) whereby the $A H I 1$ gene region has undergone a selective sweep in non-African populations. In line with this view, we noticed that 5 derived alleles have reached fixation in the CEU sample while remaining polymorphic in YRI (Fig. 2); in order to evaluate whether this feature is unusual for a neutrally evolving region, we performed 10,000 coalescent simulations by applying a calibrated population genetics model that incorporates demographic scenarios (83). The results indicated the probability of observing $\geq 5$ fixed derived alleles in CEU amounts to 0.025 , therefore supporting that $A H I 1$ has been the target of positive selection in this population.

\section{Haplotype analysis}

We next analyzed the haplotype genealogy of the $A H I 1$ gene region corresponding to the second haplotype block along the gene (Fig. 6) by a median-joining network; this region comprises the $11-\mathrm{kb}$ resequenced portion, some SNPs strongly associated with schizo- phrenia in our sample and 6 polymorphic variants previously shown to define autism-susceptibility haplotypes (45). To obtain a clear picture of the genealogical relationship of schizophrenia-predisposing haplotypes within the network, the $11-\mathrm{kb}$ region was resequenced in 4 TKT subjects: 3 of them affected with schizophrenia and 1 healthy individual. The haplotype data generated from the resequenced gene region were merged with HapMap data (for CEU and YRI) and with our SNP genotyping data for TKT subjects. The resulting network shows that in the European population, 2 major haplotype clusters exist (clade A and B, Fig. 6), while African chromosomes are extremely different from one another and account for 25 different haplotypes. Interestingly, all TKT chromosomes from affected individuals cluster with clade A, while the 2 chromosomes from the healthy subject are closely related to clade B. For the autism-susceptibility haplotypes, we found 2 of the 6 markers (rs6570000 and rs6570004) to be monomorphic in our populations. As a consequence, only 1 susceptibility haplotype was identified in the population and an extended network analysis (not shown) indicated that it also clusters with clade A.

\section{DISCUSSION}

In previous studies (39-41), we identified by linkage and association mapping a susceptibility region for schizophrenia on the long arm of chromosome 6

TABLE 4. Results from the Mantel-Haenszel joint analysis across TKT and BT samples for the best single marker and haplotype association results in TKT sample

\begin{tabular}{|c|c|c|c|c|c|}
\hline \multirow[b]{2}{*}{ Marker } & \multicolumn{2}{|c|}{ Association $P$} & \multirow[b]{2}{*}{ Heterogeneity $P$} & \multirow[b]{2}{*}{ Pooled OR and CI95 } & \multirow[b]{2}{*}{ Gene } \\
\hline & TKT sample & BT sample & & & \\
\hline \multicolumn{6}{|l|}{ Best SNPs } \\
\hline rs7759971-C & $1.84 \mathrm{E}-06$ & $2.20 \mathrm{E}-01$ & 0.002 & $1.2(0.83-1.74)$ & AHI1 \\
\hline rs11154801-C & $6.23 \mathrm{E}-06$ & $2.13 \mathrm{E}-01$ & 0.002 & $1.2(0.83-1.75)$ & AHI1 \\
\hline rs1475069-A & $6.97 \mathrm{E}-06$ & $9.21 \mathrm{E}-01$ & 0.028 & $1.88(0.87-1.27)$ & Intergenic \\
\hline rs2038549-G & $9.70 \mathrm{E}-06$ & $9.21 \mathrm{E}-01$ & 0.035 & $1.27(0.87-1.88)$ & Intergenic \\
\hline \multicolumn{6}{|l|}{ Best haplotype windows } \\
\hline rs9389286-rs2064430-rs9321502 & $3.64 \mathrm{E}-10$ & $9.34 \mathrm{E}-01$ & 0.028 & $1.37(0.92-2.02)$ & AHI1 \\
\hline rs2064430-rs9321502-rs2244745 & $4.84 \mathrm{E}-10$ & $9.63 \mathrm{E}-01$ & 0.028 & $1.36(0.92-2.02)$ & AHI1 \\
\hline
\end{tabular}




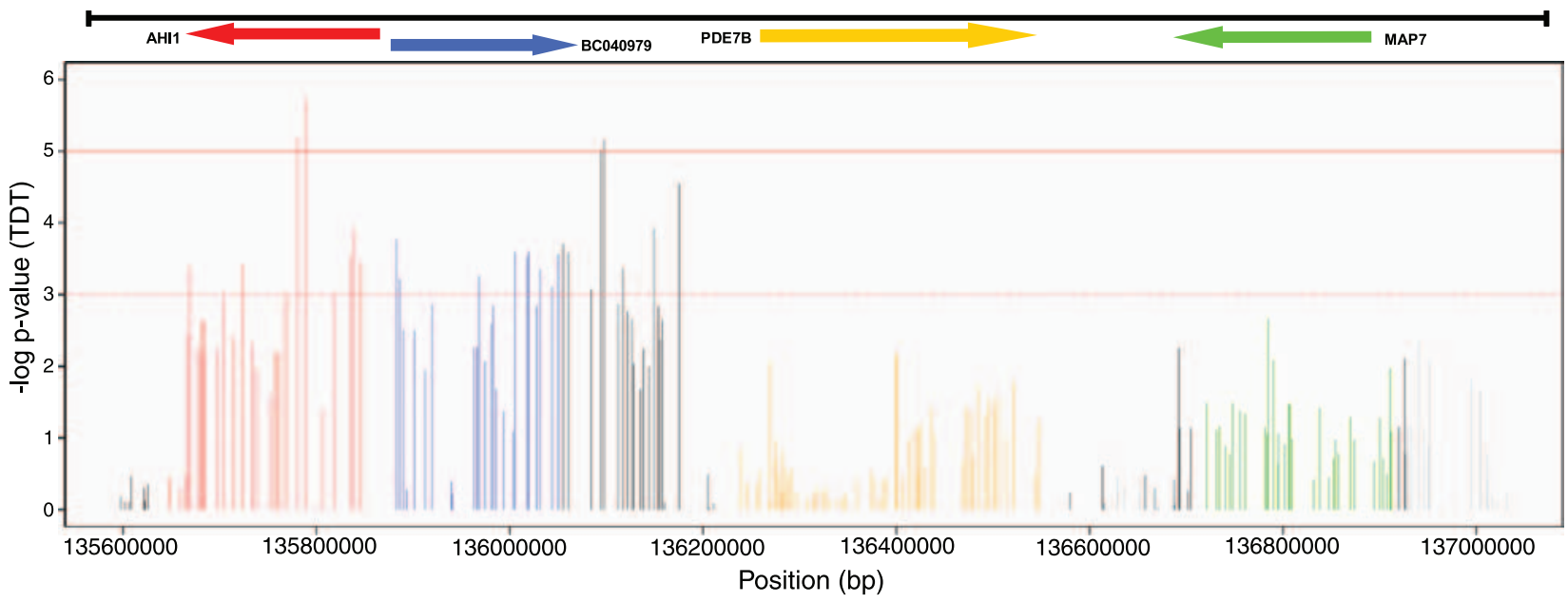

Figure 3. Plot of statistical significance $(-\log 10 P$ ) values of TDT association test of the SNPs mapping the AHI1 (red), BC040979 (blue), PDE7B (yellow), and MAP7 (green) locus (135.59-137.03 Mb, from rs4895445 to rs3765259). All intergenic SNPs are black. Reference lines indicate the thresholds for significance (solid line, $P=10 \mathrm{E}-5$; dashed line, $P=10 \mathrm{E}-3$ ).

(6q23.3). This finding was replicated in a recent independent Icelandic case control study (42). The peak region includes the Abelson helper integration site 1 gene $A H I 1$ and a putative gene encoding the humanspecific hypothalamic mRNA BC040979.

Here we have densely mapped the most probable candidates for schizophrenia by performing a fine mapping of the originally identified entire linkage region. With this uniform and denser mapping study through the entire region, as compared with the candidate gene perspective of our previous analyses, we aimed at obtaining a stronger validation of our findings.

The strongest single SNP and haplotype association, from rs6931735 and rs2614276, lies within a 500-kb genomic region (135.6-136.1 Mb) encompassing the neurodevelopmental AHI1 gene and the BC040979 locus, supporting the role of $A H I 1$ as a susceptibility

A

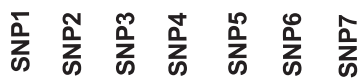

B

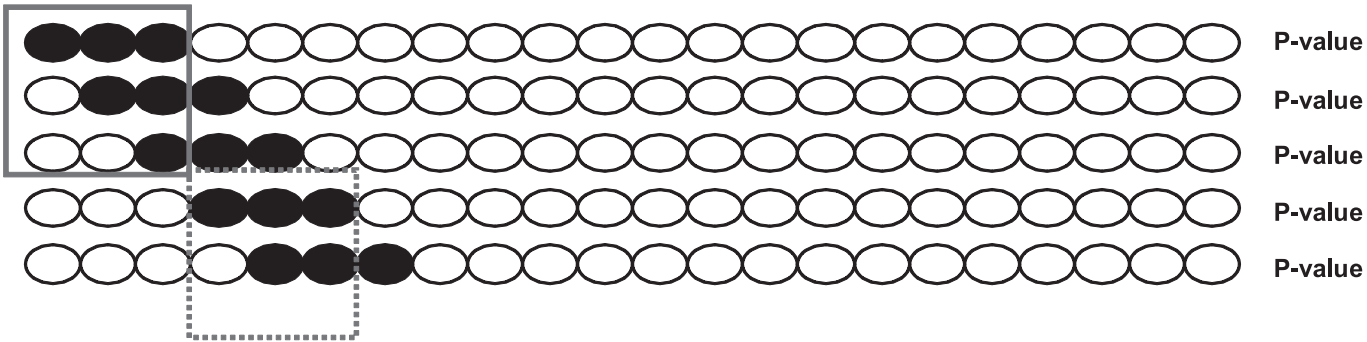

\begin{tabular}{|c|c|c|c|c|c|c|c|c|c|c|}
\hline GENE & SNP1 & SNP2 & SNP3 & \multicolumn{3}{|c|}{ HAPLOTYPE } & hap frec & $\begin{array}{c}\text { Info fam } \\
\text { (n) }\end{array}$ & p-value & q-value \\
\hline AHI1 & rs6931735 & rs6912933 & rs4896143 & A & A & $\mathrm{C}$ & 0.65 & 27 & $1.69 \mathrm{E}-07$ & $7.53 \mathrm{E}-06$ \\
\hline $\mathrm{AHI} 1$ & rs6931735 & rs6912933 & rs4896143 & $\mathrm{G}$ & $\mathrm{G}$ & $\mathrm{G}$ & 0.22 & 20 & $5.69 \mathrm{E}-05$ & $7.61 \mathrm{E}-04$ \\
\hline AHI1 & rs6912933 & rs4896143 & rs6914831 & A & C & $\mathrm{T}$ & 0.65 & 29 & $1.37 \mathrm{E}-08$ & $1.22 \mathrm{E}-06$ \\
\hline AHI1 & rs6912933 & rs4896143 & rs6914831 & $\mathrm{G}$ & $\mathrm{G}$ & $\mathrm{C}$ & 0.23 & 23 & $3.01 \mathrm{E}-05$ & 4.47E-04 \\
\hline AHI1 & rs4896143 & rs6914831 & rs9389286 & $\mathrm{C}$ & $\mathrm{T}$ & $\bar{C}$ & 0.64 & 29 & $6.69 \mathrm{E}-08$ & $3.58 \mathrm{E}-06$ \\
\hline AHI1 & rs4896143 & rs6914831 & rs9389286 & $\mathrm{G}$ & $\mathrm{C}$ & $\mathrm{G}$ & 0.23 & 23 & $9.86 \mathrm{E}-04$ & $5.19 \mathrm{E}-03$ \\
\hline AHI1 & rs6914831 & rs9389286 & rs2064430 & $\mathrm{T}$ & C & C & 0.64 & 26 & 4.04E-08 & 2.70 E-06 \\
\hline AHI1 & rs6914831 & rs9389286 & rs2064430 & C & $\mathrm{G}$ & $T$ & 0.27 & 24 & $2.38 \mathrm{E}-04$ & $2.19 \mathrm{E}-03$ \\
\hline AHI1 & rs9389286 & rs2064430 & rs9321502 & C & C & A & 0.62 & 26 & $3.64 \mathrm{E}-10$ & $6.47 \mathrm{E}-08$ \\
\hline AHI1 & rs9389286 & rs2064430 & rs9321502 & $\mathrm{G}$ & $T$ & C & 0.27 & 24 & $2.98 \mathrm{E}-06$ & 7.97E-05 \\
\hline AHI 1 & rs2064430 & rs9321502 & rs2244745 & $\mathrm{C}$ & $\mathrm{A}$ & $\mathrm{A}$ & 0.63 & 26 & $4.84 \mathrm{E}-10$ & $6.47 \mathrm{E}-08$ \\
\hline AHI1 & rs2064430 & rs9321502 & rs2244745 & $\mathrm{T}$ & C & $\mathrm{T}$ & 0.27 & 24 & $1.76 \mathrm{E}-05$ & 2.94E-04 \\
\hline AHI1 & rs9321502 & rs2244745 & rs2746430 & A & A & $\mathrm{T}$ & 0.67 & 28 & $3.13 E-07$ & 1.20E-05 \\
\hline AHI1 & rs9321502 & rs2244745 & rs2746430 & C & $T$ & A & 0.23 & 26 & $2.04 \mathrm{E}-03$ & $6.85 \mathrm{E}-03$ \\
\hline AHI1 & rs2244745 & rs2746430 & rs2614276 & A & $\mathrm{T}$ & C & 0.64 & 31 & $3.92 E-07$ & 1.31E-05 \\
\hline AHI1 & rs22244745 & rs2746430 & rs2614276 & $\mathrm{T}$ & $T$ & $\bar{C}$ & 0.05 & 10 & $3.74 \mathrm{E}-02$ & $5.03 \mathrm{E}-02$ \\
\hline AHI1 & rs2244745 & rs2746430 & rs2614276 & $T$ & $A$ & $\bar{C}$ & 0.06 & 11 & $5.43 \mathrm{E}-01$ & $3.22 \mathrm{E}-01$ \\
\hline AHI1 & rs 2244745 & rs 2746430 & rs2614276 & $\mathrm{T}$ & A & $T$ & 0.19 & 25 & $1.32 \mathrm{E}-03$ & $6.19 \mathrm{E}-03$ \\
\hline
\end{tabular}

Figure 4. Sliding-window haplotype analysis. A) Overview of 3-SNP sliding-window haplotype analysis strategy. $B$ ) Most significant haplotype cluster encompassed SNPs from rs6931735 and rs2614276 mapping in AHI1 gene. 


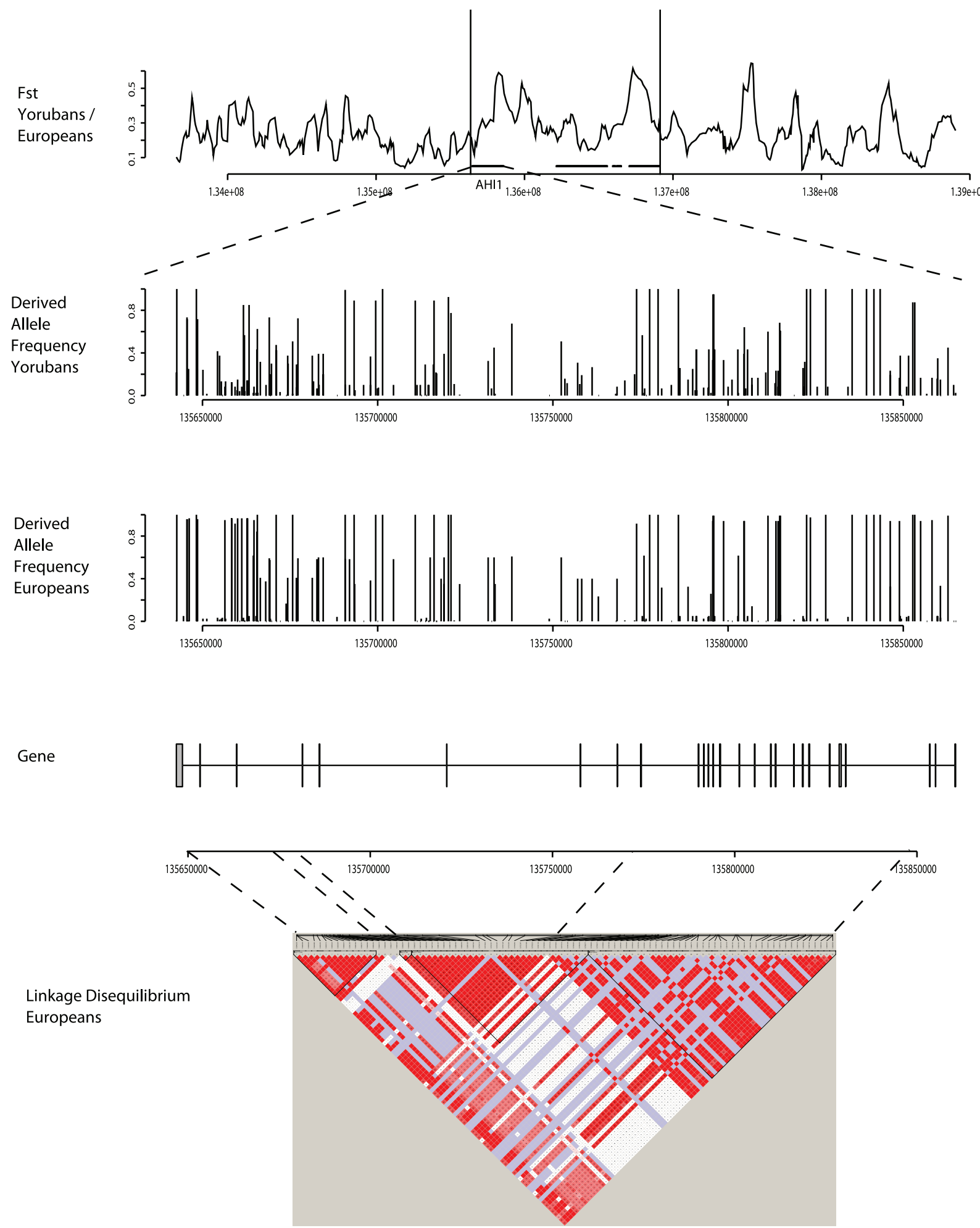

Figure 5. Analysis of $F_{\mathrm{ST}}$, allele frequency spectra, and LD using HapMap data. Top: Sliding-window analysis of $F_{\mathrm{ST}}$ between YRI and CEU in a 5-Mb region centered around the AHI1-MAP7 genomic interval. Windows of 60 SNPs with a step of 20 were used. Middle: Derived allele frequencies for YRI and CEU; SNPs with AHI1 are shown; each variant position is represented with a vertical line. Intron-exon structure of the gene is shown beneath. Bottom: linkage disequilibrium blocks in CEU.

gene for schizophrenia. The known features of AHII make it a very attractive candidate gene to schizophrenia, even if its biological function has not been yet completely elucidated.

AHI1 is expressed at high levels in both fetal and adult brain, in particular in brain areas putatively involved in schizophrenia (cerebral cortex, hippocampus, and mesolimbic pathway; refs. 92, 93) and seems to be involved in brain development (43). Mutations in this gene cause 1 form of Joubert syndrome (JS-OMIM: 
TABLE 5. Summary statistics for the evolutionary analysis of the AHI1 gene region

\begin{tabular}{|c|c|c|c|c|c|c|c|c|c|c|c|c|}
\hline \multirow[b]{2}{*}{ Pop. } & \multicolumn{2}{|c|}{$\theta_{\mathrm{W}}{ }^{a}$} & \multicolumn{2}{|c|}{$\pi^{a}$} & \multicolumn{2}{|l|}{$D_{\mathrm{T}}^{b}$} & \multicolumn{2}{|l|}{$D^{* b}$} & \multicolumn{2}{|l|}{$F^{* b}$} & \multicolumn{2}{|c|}{$\mathrm{EW}^{c}$} \\
\hline & Value & Rank & Value & Rank & Value & Rank & Value & Rank & Value & Rank & $F$ & $P$ \\
\hline YRI & 8.81 & 0.30 & 6.68 & 0.27 & $-0.86(0.37)$ & 0.26 & $0.07(0.21)$ & 0.70 & $-0.30(0.32)$ & 0.61 & 0.060 & 0.17 \\
\hline EU & 2.66 & 0.12 & 2.82 & 0.16 & $0.19(0.41)$ & 0.60 & $-1.38(0.13)$ & 0.18 & $-1.02(0.19)$ & 0.24 & 0.39 & 0.056 \\
\hline
\end{tabular}

Pop., population; EW, Ewens-Watterson. ${ }^{a}$ Estimation per site $\left(\times 10^{-4}\right) .{ }^{b} P$ values in parenthesis were obtained by applying a calibrated population genetics model; rank is by percentile relative to the distribution of 238 NIEHS genes. EW homozygosity test of neutrality with Slatkin's exact $P$ value.

213300; ref. 44), a rare recessive brain disorder characterized by complex congenital brain stem malformations. The main feature of JS is the lack of corticospinal tract and superior cerebellar peduncles $(94,95)$ due to abnormal axonal guidance or neuronal differentiation processes. AHII has been proposed as a potential downstream effector of axon guidance pathways. Interestingly, the AHII locus appears to be associated to another neurodevelopmental psychiatric disorder as autism, even if with different alleles than schizophrenia (45). Moreover, $\sim 25 \%$ of JS patients show features of autistic disorder (46). These convergences on the AHII locus suggest that it may have an important role in human cognition and behavior. Our data support this hypothesis showing that susceptibility haplotypes for schizophrenia and autism cluster in the same clade.

A recent molecular finding in mice (96) shows that AHI1 interacts with Hungtingtin-associated protein 1 (Hap1), which is involved in intracellular trafficking and TrkB (tyrosine kinase type B) receptor internalization. AHI1 and Hapl form stable protein complex structures identical to the stigmoid bodies seen in neurons where AHI1 has a preferential localization, hippocampus and brainstem (97). Stigmoid bodies have been suggested to be involved in many processes (RNA storage center, an inactive microtubule organizing center, vesicular trafficking, and a direct inhibitor of mitosis or a marker of postmitotic events; ref. 98). This scenario fits with the contemporary presence of domains (SH3, WD40) involved in specific proteinprotein interactions. Moreover, TrkB plays a role in neuronal differentiation and brain development through the signaling cascade activated by the brain-derived neurotrophic factor (BDNF; refs. 99, 100). BDNF is a potential susceptibility gene for schizophrenia (101, 102) with multiple studies reporting a deficit of $B D N F$ in the prefrontal cortex of schizophrenic patients (103, 104). These data all together suggest that AHII could play a role in cell signaling and intracellular trafficking $(105)$.

TABLE 6. Summary statistics by population for the evolutionary analysis of the AHI1 gene region

\begin{tabular}{lccrrrr}
\hline \hline & \multicolumn{3}{c}{ YRI } & & \multicolumn{2}{c}{$\mathrm{EU}$} \\
\cline { 2 - 3 } \cline { 5 - 6 } Fixed substitutions & $k$ & & & $k$ & $P$ \\
\hline 92 & 1.62 & 0.78 & & 0.52 & 0.047 \\
\hline
\end{tabular}

$k$, selection parameter.
The association of a crucial gene for neurodevelopment like AHI1 is consistent with the neurodevelopmental model of schizophrenia $(7,106)$, which is the prevailing disease model to date.

The region where we detected the strongest association to schizophrenia also includes BC040979, a gene with brain expression whose function has not been already clarified. BC040979 lies in close vicinity to AHI1, within the same large LD block, and interestingly they are transcribed in opposite directions with their $5^{\prime}$ terms being only $61 \mathrm{bp}$ apart: this raises the possibility that they are transcribed in a way that is strictly interdependent with the transcription state of the other one.

We also detected a strong association signal with 2 markers, rs2038549 and rs1475069, mapping in the region between the $3^{\prime}$ of $\mathrm{BC} 040979$ and the $5^{\prime}$ of $P D E 7 B$. These markers do not belong to the LD block containing $P D E 7 B$, but it is possible that transcription regulatory elements in $\mathrm{LD}$ with our markers map in the region upstream of $P D E 7 B$.

We also found 15 SNPs that deviate from HWE in cases only: we speculate that this finding may further support association, as already shown by many authors (61-63).

Interestingly, we had suggestive hits in the region that includes the $P D E 7 B$ and $M A P 7$ genes, even if the mapping SNPs did not survive correction for multiple testings. Given that they do not lie inside the same LD block, despite being adjacent, it is possible to exclude that the association signals detected are merely due to $\mathrm{LD}$ to $A H I 1$. Although to date a direct interaction among $P D E 7 B, M A P 7$, and $A H I 1$ has not been reported, there is evidence of a possible functional interaction. In fact $A H I 1$ and $M A P 7$ are predicted to be functional partners of $P D E 7 B$, as shown in Fig. 7, with a possible functional overlap between their pathways.

$P D E 7 B$ belongs to the large superfamily of phosphodiesterases and is involved in the control of cAMPmediated neural activity and cAMP metabolism in the brain (107). PDE7B shows a widespread expression in human brain in many brain areas with a differential expression pattern that peaks during the hippocampal formation and in the cerebellum (108), the main brain structures affected by schizophrenia and JS, respectively.

$M A P 7$ is mainly expressed in cells of epithelial origins (109) and brain. Its putative role in schizophrenia is supported by multiple findings. First, it is involved in microtubule stabilization, and schizophrenia has been associated with DISC1, a multifunctional protein acting 
Figure 6. Genealogy of AHI1 haplotypes reconstructed through a median-joining network. Region corresponding to the second LD block was analyzed, as described in the text. Each node represents a different haplotype, with the size of the circle proportional to the haplotype frequency. Colors indicate population: red, YRI; blue, CEU; gray, affected TKT subjects; green, healthy TKT subjects. Chimpanzee sequence is shown as a black circle. Nucleotide differences between haplotypes are indicated on the branches.

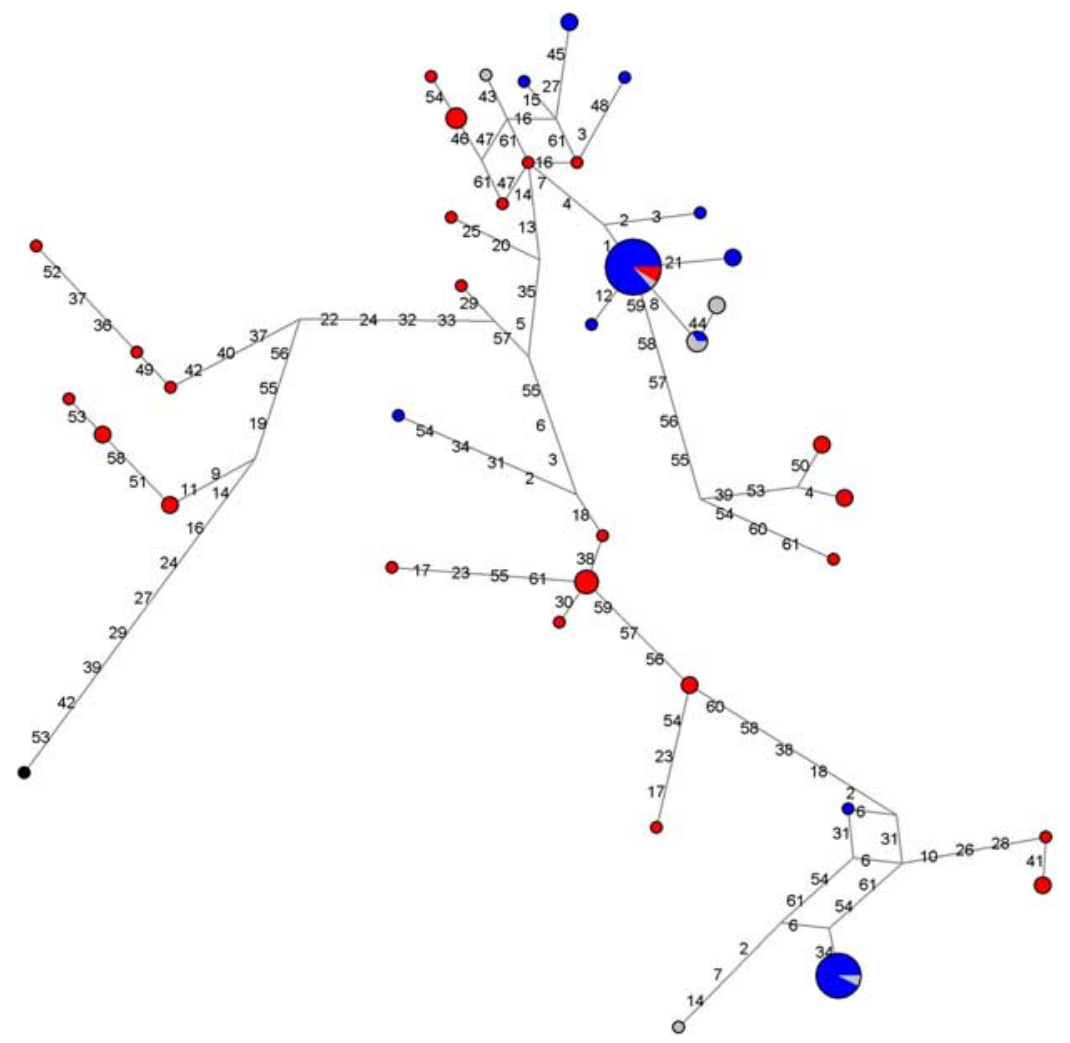

on microtubules (110). Second, MAP7 acts as a stable tubule-only polypeptide (STOP; ref. 111) protein, and STOP suppression in mice was shown to affect both long- and short-term synaptic plasticity in the hippocampus, to deplete vesicular pools in glutamatergic nerve terminals and to cause severe behavioral disorders (112). Recently, it has also been reported that
STOP-null mice models for schizophrenia, together with deficit in both recognition and long-term potentiation, show neuroanatomical deficits that in some way are reminiscent of those observed among individuals with schizophrenia (113).

Even if we do not propose a model of interaction between those genes and known candidate genes for

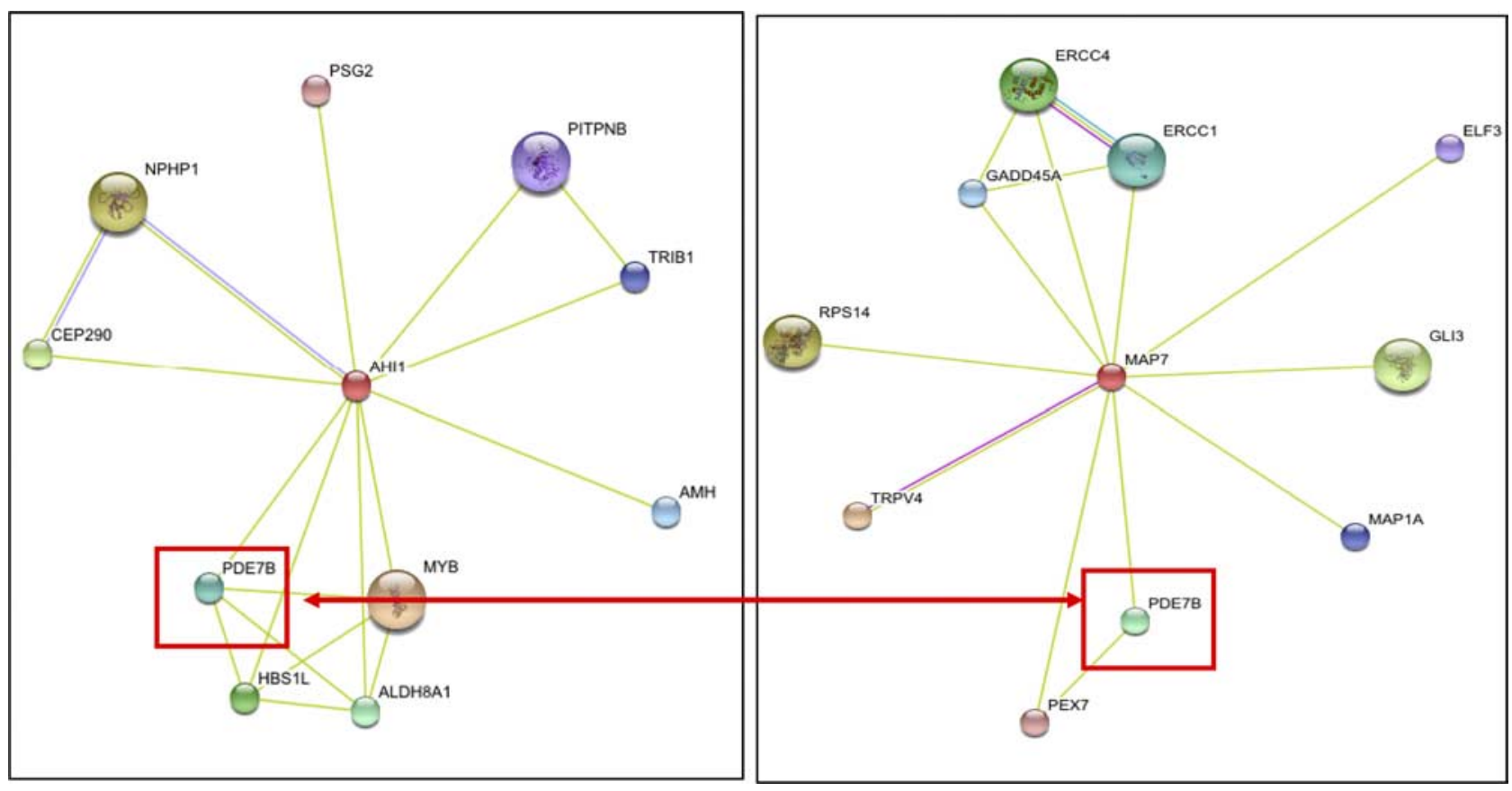

Figure 7. Plots of predicted interaction partnership of the $A H I 1$ and $M A P 7$ genes. Red rectangles indicate the $P D E 7 B$ gene that interacts with both $A H I 1$ and $M A P 7$. Although a direct interaction between those genes has not been reported to date, $A H I 1$ and $M A P 7$ converge on the $P D E 7 B$ gene in terms of predicted functional interaction. 
schizophrenia, there are multiple links between them that can be found by simple information retrieving. Figure 8 shows some of the most interesting interactors of $A H I 1, P D E 7 B$, and $M A P 7$, many of which are candidate genes to schizophrenia or are involved in other brain pathways and processes.

The apparent paradox by which schizophrenia-predisposing alleles have been maintained in human populations despite the fitness cost and fertility reduction experienced by the affected subjects has led in recent years to much scientific debate (114-118). Different evolutionary "payoffs" for the maintenance of susceptibility alleles have been invoked $(117,118)$. Conversely, other authors suggested that an evolutionary model based on polygenic mutation-selection balance properly fits the available data on common mental disorders (116). Yet, evidence in support of either hypothesis has been lacking. A comprehensive analysis (49) of known genes involved in schizophrenia indicated that evidence for positive selection can be identified in a number of cases. Consistently, other researchers (119) reported that a portion of genes involved in brain metabolic processes affected in schizophrenia might have undergone adaptive evolution in humans. The data we report here support the previous indication (51) that AHI1 has undergone a selective sweep in Europeans. Most neutrality tests failed to reject neutral evolution at AHI1; yet recent works $(81,120,121)$ addressed the power of these commonly used statistics to reject neutrality and indicated that the strength and timing of the selective pressure, as well as the allele frequency of the selected allele and its location relative to the resequenced region can heavily affect statistical power. Our data indicate that the 11-kb region we resequenced displays a significant reduction of polymorphisms compared with divergence, as addressed by the MLHKA test, which is among the most powerful tests for positive selection (121). Indeed, we also noticed that the number of derived alleles that reached fixation in Europeans is higher than expected under neutrality while being polymorphic in Yorubans. These data therefore fit the hypothesis that genes involved in schizophrenia are frequent targets of natural selection. Still, inference about non-neutral evolution alone does not provide insight into the relationship between schizophrenia-predisposing alleles and selective processes. Specifically, the question whether risk alleles have been selected for (because they conferred some advantage in specific circumstances) or against (because they represented maladaptive variants in relation to either mental disorders or other traits) remains open. Alternatively, schizophrenia risk alleles might have hitchhiked with variants subjected to positive selection rather than being the selection target themselves. Re-

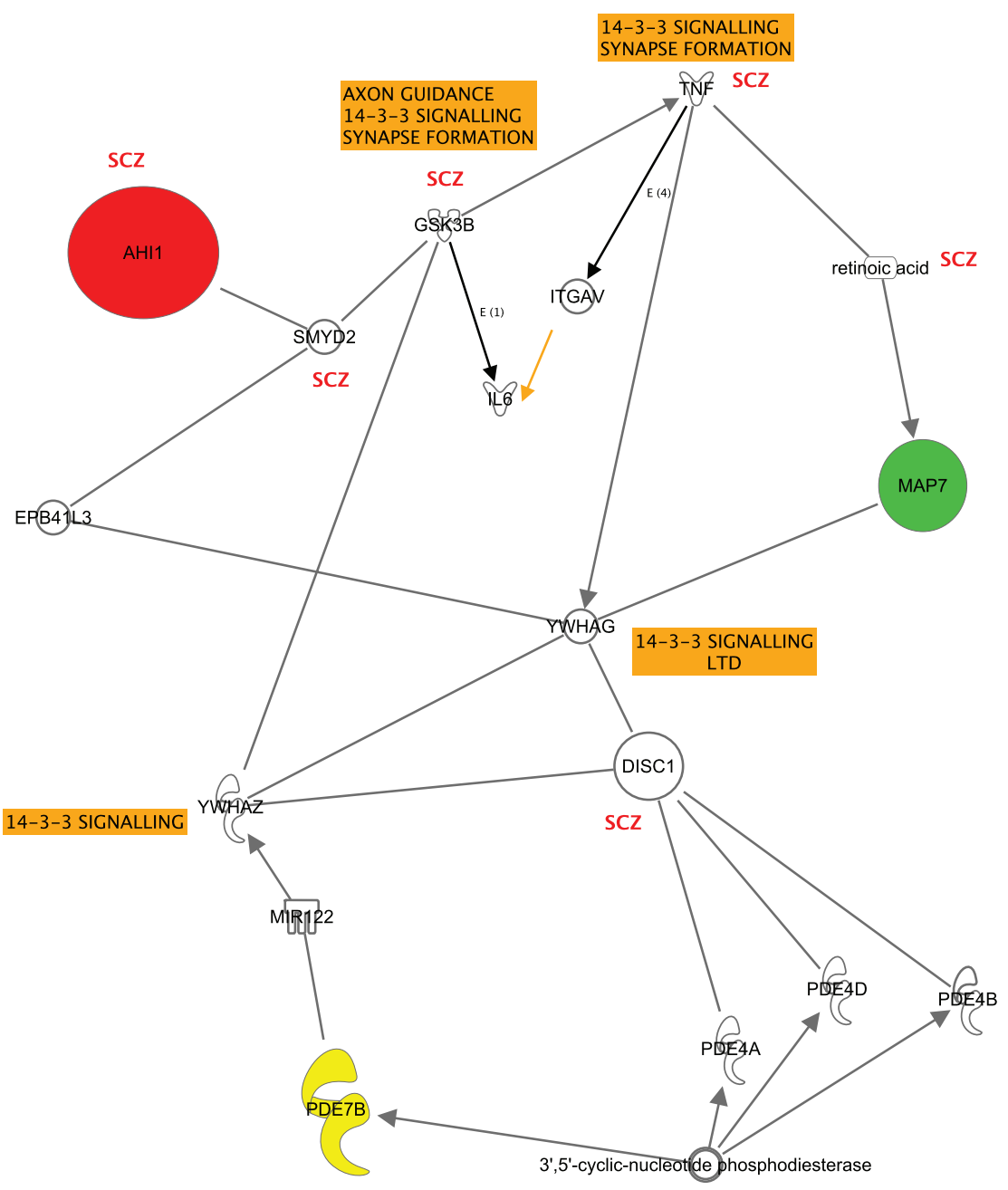

Figure 8. Plots of one of the hypothetical networks linking AHI1, PDE7B, and MAP7. Some of their partners shown have been previously reported to be involved in schizophrenia and in other brain pathways or processes. 
cently, Carrera et al. (122) indicated that the ancestral susceptibility model might apply to schizophrenia for variants in $M A O B$. This same model does not fit $A H I 1$ data, as indicated by our haplotype analysis. Indeed, schizophrenia susceptibility haplotypes cluster with a major haplotype clade, suggesting that they have risen in frequency possibly through hitchhiking with a linked selected allele. Similar findings have been reported for DRD4 (123) for which susceptibility variants for schizophrenia and other behavioral disturbances (e.g., ADHD) have increased in human populations due to positive selection and linkage to the 7-repeat allele of a $48 \mathrm{bp}$ tandem repeat. Similarly, the $\alpha-2$ allele of haptoglobin, which has also been associated with schizophrenia (10), is thought to have rapidly spread among humans due to its conferring stronger immune response (124).

Overall, these data indicate that further studies are required to address the link between schizophrenia predisposition and selective events, since the underlying evolutionary model (if any) might be different at distinct loci.

Our data confirm and definitely support the role of AHI1 as a susceptibility gene for schizophrenia, confirm its being subjected to positive selection, and even shed light on new possible candidates like $M A P 7$ and $P D E 7 B$ that putatively interact with genes that have been previously reported to be involved in schizophrenia and in other brain pathways or processes. Nevertheless, as this locus is still not mapped with the highest resolution possible, this assignment has to be considered preliminary to deep sequencing, which is by now the most advanced technique to map loci associated with complex diseases. Sequencing will also allow us to determine the regulatory elements of this locus, which will help us to understand how AHI1 expression is regulated.

The study was conceived and designed by F.M., B.L., and D.A. The DNA samples were prepared by D.A. and A.A. and genotyped by F.T. and C.D.F. Analyses were performed by F.T., S.L., M.S., M.F., and A.A. C.B. supervised the genotyping and F.M. the analysis. The manuscript was written by F.T. with contributions from F.M., M.S., L.S.L., J.S.B., and B.L. All authors read and approved the manuscript. The authors thank Dr. Adnan Hamdan for assistance in recruitment and Alexandra Slonimsky for assistance with preparation of DNA samples. This work was supported by FIRB ItaliaIsraele (RBIN04SWHR), a fellowship of the Doctorate School of Molecular Medicine, University of Milan, POCEMON (FP7-ICT-2007-216088), Hypergenes (Health-F4-2007201550), InGenious HyperCare (LSHM-CT-2006-037093), and the Israel Science Foundation (Israel Academy of Sciences, grant 348/09).

\section{REFERENCES}

1. Owen, M. J., O'Donovan, M. C., and Gottesman, I. I. (2002) Schizophrenia. In Psychiatric Genetics $\mathcal{E}$ Genomics (McGuffin, P., Owen, M.J., and Gottesman, I.I., eds) pp. 247-266, Oxford University Press, Oxford, UK

2. McGuffin, P., Asherson, P., Owen, M., and Farmer, A. (1994) The strength of the genetic effect. Is there room for an environmental influence in the aetiology of schizophrenia? Br.J. Psych. 64, 593-599

3. McGue, M., and Gottesman, I. I. (1989) A single dominant gene still cannot account for the transmission of schizophrenia. Arch. Gen. Psych. 46, 478-480
4. Lichtermann, D., Karbe, E., and Maier, W. (2000) The genetic epidemiology of schizophrenia and of schizophrenia spectrum disorders. Eur. Arch. Psychiatry Clin. Neurosci. 250, 304-310

5. Badner, J. A., and Gershon, E. S. (2002) Meta-analysis of whole-genome linkage scans of bipolar disorder and schizophrenia. Mol. Psychiatr. 7, 405-411

6. Ng, M. Y., Levinson, D. F., Faraone, S. V., Suarez, B. K., Delisi, L. E., Arinami, T., Riley, B., Paunio, T., Pulver, A. E., Irmansyah, Holmans, P. A., Escamilla, M., Wildenauer, D. B., Williams, N. M., Laurent, C., Mowry, B. J., Brzustowicz, L. M., Maziade, M., Sklar, P., Garver, D. L., Abecasis, G. R., Lerer, B., Fallin, M. D., Gurling, H. M., Gejman, P. V., Lindholm, E., Moises, H. W., Byerley, W., Wijsman, E. M., Forabosco, P., Tsuang, M. T., Hwu, H. G., Okazaki, Y., Kendler, K. S., Wormley, B., Fanous, A., Walsh, D., O’Neill, F. A., Peltonen, L., Nestadt, G., Lasseter, V. K., Liang, K. Y., Papadimitriou, G. M., Dikeos, D. G., Schwab, S. G., Owen, M. J., O'Donovan, M. C., Norton, N., Hare, E., Raventos, H., Nicolini, H., Albus, M., Maier, W., Nimgaonkar, V. L., Terenius, L., Mallet, J., Jay, M., Godard, S., Nertney, D., Alexander, M., Crowe, R. R., Silverman, J. M., Bassett, A. S., Roy, M. A., Mérette, C., Pato, C. N., Pato, M. T., Roos, J. L., Kohn, Y., Amann-Zalcenstein, D., Kalsi, G., McQuillin, A., Curtis, D., Brynjolfson, J., Sigmundsson, T., Petursson, H., Sanders, A. R., Duan, J., Jazin, E., Myles-Worsley, M., Karayiorgou, M., and Lewis, C. M. (2009) Meta-analysis of 32 genome-wide linkage studies of schizophrenia. Mol. Psych. 14, 774-785

7. Lewis, C. M., Levinson, D. F., Wise, L. H., DeLisi, L. E., Straub, R. E., Hovatta, I., Williams, N. M., Schwab, S. G., Pulver, A. E., Faraone, S.V. Brzustowicz, L. M., Kaufmann, C. A., Garver, D. L., Gurling, H. M., Lindholm, E., Coon, H., Moises, H. W., Byerley, W., Shaw, S. H., Mesen, A., Sherrington, R., O’Neill, F. A., Walsh, D., Kendler, K. S., Ekelund, J., Paunio, T., Lönnqvist, J., Peltonen, L., O’Donovan, M. C., Owen, M. J., Wildenauer, D. B., Maier, W., Nestadt, G., Blouin, J. L., Antonarakis, S. E., Mowry, B. J., Silverman, J. M., Crowe, R. R., Cloninger, C. R., Tsuang, M. T., Malaspina, D., Harkavy-Friedman, J. M., Svrakic, D. M., Bassett, A. S., Holcomb, J., Kalsi, G., McQuillin, A., Brynjolfson, J., Sigmundsson, T., Petursson, H., Jazin, E., Zoëga, T., and Helgason, T. (2003) Genome scan meta-analysis of schizophrenia and bipolar disorder. Part II: schizophrenia. Am. J. Hum. Genet. 73, 34-48

8. Kohn, Y., and Lerer, B. (2002) Genetics of schizophrenialinkage findings: a review. Israel J. Psychiatry Rel. Sci. 39, 240-251

9. Kohn, Y., and Lerer, B. (2005) Excitement and confusion on chromosome 6q: the challenges of neuropsychiatric genetics in microcosm. Mol. Psychiatry 10, 1062-1073

10. Allen, N. C., Bagade, S., McQueen, M. B., Ioannidis, J. P., Kavvoura, F. K., Khoury, M. J., Tanzi, R. E., and Bertram, L. (2008) Systematic meta-analyses and field synopsis of genetic association studies in schizophrenia: the SzGene database. Nat. Genet. 40, 827-834

11. Lencz, T., Morgan, T. V., Athanasiou, M., Dain, B., Reed, C. R., Kane, J. M., Kucherlapati, R., and Malhotra, A. K. (2007) Converging evidence for a pseudoautosomal cytokine receptor gene locus in schizophrenia. Mol. Psychiatry 12, 572-580

12. Shifman, S., Johannesson, M., Bronstein, M., Chen, S. X., Collier, D.A ., Craddock, N. J., Kendler, K. S., Li, T., O'Donovan, M., O’Neill, F. A, Owen, M. J., Walsh, D., Weinberger, D. R. Sun, C., Flint, J., and Darvasi, A. (2008) Genome-wide association identifies a common variant in the reelin gene that increases the risk of schizophrenia only in women. PLoS Genet. 4, e28

13. Kirov, G., Zaharieva, I., Georgieva, L., Moskvina, V., Nikolov, I., Cichon, S., Hillmer, A., Toncheva, D., Owen, M. J., and O'Donovan, M. C. (2009) A genome-wide association study in 574 schizophrenia trios using DNA pooling. Mol. Psychiatry 14, $796-803$

14. Sullivan, P. F., Lin, D., Tzeng, J. Y., Van den Oord, E., Perkins, D., Stroup, T. S., Wagner, M., Lee, S., Wright, F. A., Zou, F., Liu, W., Downing, A. M., Lieberman, J., and Close, S. L. (2008) Genomewide association for schizophrenia in the CATIE study: results of stage 1. Mol. Psychiatry 13, 570-584

15. O'Donovan, M. C., Craddock, N., Norton, N., Williams, H., Peirce, T., Moskvina, V., Nikolov, I., Hamshere, M., Carroll, L., Georgieva, L., Dwyer, S., Holmans, P., Marchini, J. L., Spencer, C. C., Howie, B., Leung, H. T., Hartmann, A. M., Möller, H. J., Morris, D. W., Shi, Y., Feng, G., Hoffmann, P., Propping, P., 
Vasilescu, C., Maier, W., Rietschel, M., Zammit, S., Schumacher, J., Quinn, E. M., Schulze, T. G., Williams, N. M., Giegling, I., Iwata, N., Ikeda, M., Darvasi, A., Shifman, S., He, L., Duan, J., Sanders, A. R., Levinson, D. F., Gejman, P. V., Cichon, S., Nöthen, M. M., Gill, M., Corvin, A., Rujescu, D., Kirov, G., Owen, M. J., Buccola, N. G., Mowry, B. J., Freedman, R., Amin, F., Black, D. W., Silverman, J. M., Byerley, W. F., and Cloninger, C. R.; Molecular Genetics of Schizophrenia Collaboration. (2008) Identification of loci associated with schizophrenia by genome-wide association and follow-up. Nat. Genet. 40, 1053-1055

16. Need, A. C., Ge, D., Weale, M. E., Maia, J., Feng, S., Heinzen, E. L., Shianna, K. V., Yoon, W., Kasperaviciute, D., Gennarelli, M. Strittmatter, W. J., Bonvicini, C., Rossi, G., Jayathilake, K., Cola, P. A., McEvoy, J. P., Keefe, R. S., Fisher, E. M., St Jean, P. L., Giegling, I., Hartmann, A. M., Möller, H. J., Ruppert, A., Fraser, G., Crombie, C., Middleton, L. T., St Clair, D., Roses, A. D., Muglia, P., Francks, C., Rujescu, D., Meltzer, H. Y., and Goldstein, D. B. (2009) A genome-wide investigation of SNPs and CNVs in schizophrenia. PLoS Genet. 5, e1000373

17. Shi, J., Levinson, D. F., Duan, J., Sanders, A. R., Zheng, Y., Pe'er, I., Dudbridge, F., Holmans, P. A., Whittemore, A. S., Mowry, B. J., Olincy, A., Amin, F., Cloninger, C. R., Silverman, J. M., Buccola, N. G., Byerley, W. F., Black, D. W., Crowe, R. R., Oksenberg, J. R., Mirel, D. B., Kendler, K. S., Freedman, R., and Gejman, P. V. (2009) Common variants on chromosome 6p22.1 are associated with schizophrenia. Nature 6, 753-757

18. International Schizophrenia Consortium (2009) Common polygenic variation contributes to risk of schizophrenia and bipolar disorder. Nature 6, 748-752

19. Potkin, S. G., Turner, J. A., Fallon, J. A., Lakatos, A., Keator, D. B., Guffanti, G., and Macciardi, F. (2009) Gene discovery through imaging genetics: identification of two novel genes associated with schizophrenia. Mol. Psychiatry 14, 416-428

20. Potkin, S. G., Turner, J. A., Guffanti, G., Lakatos, A., Fallon, J. H., Nguyen, D. D., Mathalon, D., Ford, J., Lauriello, J., and Macciardi, F. (2009) A genome-wide association study of schizophrenia using brain activation as a quantitative phenotype. Schizophr. Bull. 35, 96-108

21. Walsh, T., McClellan, J. M., McCarthy, S. E., Addington, A. M., Pierce, S. B., Cooper, G. M., Nord, A. S., Kusenda, M., Malhotra, D., Bhandari, A., Stray, S. M., Rippey, C. F., Roccanova, P., Makarov, V., Lakshmi, B., Findling, R. L., Sikich, L., Stromberg, T., Merriman, B., Gogtay, N., Butler, P., Eckstrand, K., Noory, L., Gochman, P., Long, R., Chen, Z., Davis, S., Baker, C., Eichler, E. E., Meltzer, P. S., Nelson, S. F., Singleton, A. B., Lee, M. K., Rapoport, J. L., King, M. C., and Sebat, J. (2008) Rare structural variants disrupt multiple genes in neurodevelopmental pathways in schizophrenia. Science 320, 539-543

22. Xu, B., Roos, J. L., Levy, S., Van Rensburg, E. J., Gogos, J. A., and Karayiorgou, M. (2008) Strong association of de novo copy number mutations with sporadic schizophrenia. Nat. Genet. 40, $880-885$

23. Stefansson, H., Rujescu, D., Cichon, S., Pietilainen, O. P., Ingason, A., Steinberg, S., Fossdal, R., Sigurdsson, E., Sigmundsson, T., Buizer-Voskamp, J. E., Hansen, T., Jakobsen, K. D., Muglia, P., Francks, C., Matthews, P. M., Gylfason, A., Halldorsson, B. V., Gudbjartsson, D., Thorgeirsson, T. E., Sigurdsson, A., Jonasdottir, A., Jonasdottir, A., Bjornsson, A., Mattiasdottir, S., Blondal, T., Haraldsson, M., Magnusdottir, B. B., Giegling, I., Möller, H. J., Hartmann, A., Shianna, K. V., Ge, D., Need, A. C., Crombie, C., Fraser, G., Walker, N., Lonnqvist, J., Suvisaari, J., Tuulio-Henriksson, A., Paunio, T., Toulopoulou, T., Bramon, E., Di Forti, M., Murray, R., Ruggeri, M., Vassos, E., Tosato, S., Walshe, M., Li, T., Vasilescu, C., Mühleisen, T. W., Wang, A. G., Ullum, H., Djurovic, S., Melle, I., Olesen, J., Kiemeney, L. A., Franke, B.; GROUP, Sabatti, C., Freimer, N. B., Gulcher, J. R., Thorsteinsdottir, U., Kong, A., Andreassen, O. A., Ophoff, R. A., Georgi, A., Rietschel, M., Werge, T., Petursson, H., Goldstein, D. B., Nöthen, M. M., Peltonen, L., Collier, D. A., St Clair, D., and Stefansson, K. (2008) Large recurrent microdeletions associated with schizophrenia. Nature 455, 232-236

24. The International Schizophrenia Consortium (2008) Rare chromosomal deletions and duplications increase risk of schizophrenia. Nature 455, 237-241

25. Rapoport, J. L., Addington, A. M., Frangou, S., and Psych, M. R. (2005) The neurodevelopmental model of schizophrenia: update 2005. Mol. Psychiatry 10, 434-449
26. Harrison, P. J., and Owen, M. J. (2003) Genes for schizophrenia? Recent findings and their pathophysiological implications. Lancet 361, 417-419

27. Riley, B. P., and McGuffin, P. (2000) Linkage and associated studies of schizophrenia. Am. J. Med. Genet. 97, 23-44

28. Cao, Q., Martinez, M., Zhang, J., Sanders, A. R., Badner, J. A., Cravchik, A., Markey, C. J., Beshah, E., Guroff, J. J., Maxwell, M. E., Kazuba, D. M., Whiten, R., Goldin, L. R., Gershon, E. S. and Gejman, P. V. (1997) Suggestive evidence for a schizophrenia susceptibility locus on chromosome $6 \mathrm{q}$ and a confirmation in an independent series of pedigrees. Genomics 43, 1-8

29. Kaufmann, C. A., Suarez, B., Malaspina, D., Pepple, J., Svrakic, D., Markel, P. D., Meyer, J., Zambuto, C. T., Schmitt, K., Matise, T. C., Harkavy Friedman, J. M., Hampe, C., Lee, H., Shore, D., Wynne, D., Faraone, S. V., Tsuang, M. T., and Cloninger, C. R. (1998) NIMH Genetics Initiative Millenium Schizophrenia Consortium: linkage analysis of African-American pedigrees. Am. J Med. Genet. 81, 282-289

30. Martinez, M., Goldin, L. R., Cao, Q., Zhang, J., Sanders, A. R., Nancarrow, D. J., Taylor, J. M., Levinson, D. F., Kirby, A., Crowe, R. R., Andreasen, N. C., Black, D. W., Silverman, J. M., Lennon, D. P., Nertney, D. A., Brown, D. M., Mowry, B. J., Gershon, E. S., and Gejman, P.V. (1999) Follow-up study on a susceptibility locus for schizophrenia on chromosome 6q. Am. J. Med. Genet. 88, 337-343

31. Bailer, U., Leisch, F., Meszaros, K., Lenzinger, E., Willinger, Strobl, U. R., Heiden, A., Gebhardt, C., Döge, E., Fuchs, K., Sieghart, W., Kasper, S., Hornik, K., and Aschauer, H. N. (2002) Genome scan for susceptibility loci for schizophrenia and bipolar disorder. Biol. Psychiatry 52, 40-52

32. Levinson, D. F., Holmans, P., Straub, R. E., Owen, M. J., Wildenauer, D. B., Gejman, P. V., Pulver, A. E., Laurent, C., Kendler, K. S., Walsh, D., Norton, N., Williams, N. M., Schwab, S. G., Lerer, B., Mowry, B. I., Sanders, A. R., Antonarakis, S. E., Blouin, J. L., DeLeuze, J. F., and Mallet, J. (2000) Multicenter linkage study of schizophrenia candidate regions on chromosomes 5q, 6q, 10p, and 13q: schizophrenia linkage collaborative group III. Am. J. Hum. Genet. 67, 652-663

33. Lindholm, E., Ekholm, B., Shaw, S., Jalonen, P., Johansson, G. Pettersson, U., Sherrington, R., Adolfsson, R., and Jazin, E. (2001) A schizophrenia-susceptibility locus at $6 \mathrm{q} 25$, in one of the world's largest reported pedigrees. Am. J. Hum. Genet. 69, 96-105

34. Williams, N. M., Norton, N., Williams, H., Ekholm, B., Hamshere, Lindblom, M. L. Y., ChowdariKV, Cardno, A. G., Zammit, S., Jones, L. A. Murphy, K. C., Sanders, R. D., McCarthy, G., Gray, M. Y., Jones, G., Holmans, P., Nimgaonkar, V., Adolfson, R., Osby, U., Terenius, L., Sedvall, G., O'Donovan, M. C., and Owen, M. J. (2003) A systematic genomewide linkage study in 353 sib pairs with schizophrenia. Am. J. Hum. Genet. 73, 1355-1367

35. Duan, J., Martinez, M., Sanders, A. R., Hou, C., Saitou, N., Kitano, T., Mowry, B. J., Crowe, R. R., Silverman, J. M., Levinson, D. F., and Gejman, P. V. (2004) Polymorphisms in the trace amine receptor 4 (TRAR4) gene on chromosome 6q23.2 are associated with susceptibility to schizophrenia. Am. J. Hum. Genet. 75, 624-638

36. Dick, D. M., Foroud, T., Flury, L., Bowman, E. S., Miller, M. J., Rau, N. L., Moe, P. R., Samavedy, N., El-Mallakh, R., Manji, H., Glitz, D. A., Meyer, E. T., Smiley, C., Hahn, R., Widmark, C., McKinney, R., Sutton, L., Ballas, C., Grice, D., Berrettini, W., Byerley, W., Coryell, W., DePaulo, R., MacKinnon, D. F., Gershon, E. S., Kelsoe, J. R., McMahon, F. J., McInnis, M., Murphy, D. L., Reich, T., Scheftner, W., and Nurnberger, J. I., Jr. (2003) Genome wide linkage analyses of bipolar disorder: a new sample of 250 pedigrees from the National Institute of Mental Health Genetics Initiative. Am. J. Hum. Genet. 73, 107-114

37. McInnis, M. G., Dick, D. M., Willour, V. L., Avramopoulos, D., MacKinnon, D. F., Simpson, S. G., Potash, J. B., Edenberg, H. J., Bowman, E. S., McMahon, F. J., Smiley, C., Chellis, J. L., Huo, Y., Diggs, T., Meyer, E. T., Miller, M., Matteini, A. T., Rau, N. L., DePaulo, J. R., Gershon, E. S., Badner, J. A., Rice, J. P., Goate, A. M., Detera-Wadleigh, S. D., Nurnberger, J. I., Reich, T., Zandi, P. P., and Foroud, T. M. (2003) Genome-wide scan and conditional analysis in bipolar disorder: evidence for genomic interaction in the National Institute of Mental Health genetics initiative bipolar pedigrees. Biol. Psychiatry 54, 1265-1273

38. Middleton, F. A., Pato, M. T., Gentile, K. L., Morley, C. P., Zhao, X., Eisener, A. F., Brown, A., Petryshen, T. L., Kirby, A. N., Medeiros, H., Carvalho, C., Macedo, A., Dourado, A., Coelho, I., Valente, J., 
Soares, M. J., Ferreira, C. P., Lei, M., Azevedo, M. H., Kennedy, J. L., Daly, M. J., Sklar, P., and Pato, C. N. (2004) Genomewide linkage analysis of bipolar disorder by use of a high-density single-nucleotide-polymorphism (SNP) genotyping assay: a comparison with microsatellite marker assays and finding of significant linkage to chromosome 6q22. Am. J. Hum. Genet. 74, 886-897

39. Lerer, B., Segman, R. H., Hamdan, A., Kanyas, K., Karni, O., Kohn, Y., Korner, M., Lanktree, M., Kaadan, M., Turetsky, N. Yakir, A., Kerem, B., and Macciardi, F. (2003) Genome scan of Arab Israeli families maps a schizophrenia susceptibility gene to chromosome $6 \mathrm{q} 23$ and supports a locus at chromosome 10q24. Mol. Psychiatry 8, 488-498

40. Levi, A., Kohn, Y., Kanyas, K., Amann, D., Pae, C. U., Hamdan, A., Segman, R. H., Avidan, N., Karni, O., Korner, M. J., Jun, T. Y., Beckmann, J. S., Macciardi, F., and Lerer, B. (2005) Fine mapping of a schizophrenia susceptibility locus at chromosome 6q23: increased evidence for linkage and reduced linkage interval. Eur. J. Hum. Genet. 13, 763-771

41. Amann-Zalcenstein, D., Avidan, N., Kanyas, K., Ebstein, R. P., Kohn, Y., Hamdan, A., Ben-Asher, E., Karni, O., Mujaheed, M., Segman, R. H., Maier, W., Macciardi, F., Beckmann, J. S., Lancet, D., and Lerer, B. (2006) AHI1, a pivotal neurodevelopmental gene, and C6orf217 are associated with susceptibility to schizophrenia. Eur. J. Hum. Genet. 14, 1111-1119

42. Ingason, A., Sigmundsson, T., Steinberg, S., Sigurdsson, E., Haraldsson, M., Magnusdottir, B. B., Frigge, M. L., Kong, A., Gulcher, J., Thorsteinsdottir, U., Stefansson, K., Petursson, H., and Stefansson, H. (2007) Support for involvement of the AHII locus in schizophrenia. Eur. J. Hum. Genet. 15, 988-991

43. Ferland, R. J., Eyaid, W., Collura, R. V., Tully, L. D., Hill, R. S., Al-Nouri, D., Al-Rumayyan, A., Topcu, M., Gascon, G., Bodell, A., Shugart, Y. Y., Ruvolo, M., and Walsh, C. A. (2004) Abnormal cerebellar development and axonal decussation due to mutations in AHI1 in Joubert syndrome. Nat. Genet. 36, 1008-1013

44. Valente, E. M., Brancati, F., Silhavy, J. L., Castori, M., Marsh, S. E., Barrano, G., Bertini, E., Boltshauser, E., Zaki, M. S., Abdel-Aleem, A. Bellacchio, E., Battini, R., Cruse, R. P., Dobyns, W. B., Krishnamoorthy, K. S., Lagier-Tourenne, C., Magee, A., Pascual-Castroviejo, I., Salpietro, C. D., Sarco, D., Dallapiccola, B., and Gleeson, J. G.; International JSRD Study Group. (2006) AHI1 gene mutations cause specific forms of Joubert syndromerelated disorders. Ann. Neurol. 59, 527-534

45. Alvarez Retuerto, A. I., Cantor, R. M., Gleeson, J. G., Ustaszewska, A., Schackwitz, W. S., Pennacchio, L. A., and Geschwind, D. H. (2008) Association of common variants in the Joubert syndrome gene (AHI1) with autism. Hum. Mol. Genet. 17, 3887-3896

46. Ozonoff, S., Williams, B. J., Gale, S., and Miller, J. N. (1999) Autism and autistic behavior in Joubert syndrome. J. Child Neurol. 14, 636-641

47. American Psychiatric Association (1994) Diagnostic and Statistical Manual of Mental Disorders, 4th Edition, American Psychiatric Association, Washington, DC

48. Bleuler, E. (1911) Dementia præcox, oder die Gruppe der Schizophrenien. In Handbuch der Psychiatrie (Aschaffenburg, G., ed), Deuticke, Leipzig, Germany

49. Crespi, B., Summers, K., and Dorus, S. (2007) Adaptive evolution of genes underlying schizophrenia. Proc. Biol. Sci. 274, 2801-2810

50. Barreiro, L. B., Laval, G., Quach, H., Patin, E., and QuintanaMurci, L. (2008) Natural selection has driven population differentiation in modern humans. Nat. Genet. 40, 340-345

51. Yu, F., Keinan, A., Chen, H., Ferland, R. J., Hill, R. S., Mignault, A. A., Walsh, C. A., and Reich, D. (2009) Detecting natural selection by empirical comparison to random regions of the genome. Hum. Mol. Genet. 15, 4853-4867

52. Jaber, L., Bailey-Wilson, J. E., Haj-Yehia, M., Hernandez, J., and Shohat, M. (1994) Consanguineous matings in an Israeli-Arab community. Arch. Pediatr. Adolesc. Med. 148, 412-415

53. Jaber, L., Halpern, G. J., and Shohat, T. (2000) Trends in the frequencies of consanguineous marriages in the Israeli Arab community. Clin. Genet. 58, 106-110

54. Spitzer, R. L., Endicott, J. and Robins, E. (1978) Research diagnostic criteria: rationale and reliability. Arch. Gen. Psychiatry 35, 773-782

55. Andreasen, N. C., Endicott, J., Spitzer, R. L. and Winokur, G. (1977) The family history method using diagnostic criteria. Reliability and validity. Arch. Gen. Psychiatry 34, 1229-1235
56. Baron, M., Endicott, J., Lerer, B., Loth, J. E., Alexander, J. R., Simon, R., Sharpe, L., Gibbon, M., Hasin, D., Lilliston, B., Schacht, S., Blumenthal, R., Alexander, J., Verter, A., Tubi, N., Fieve, R. R., Gilliam, T. C., Lehner, T., and Ott, J. (1994) A pedigree series for mapping disease genes in bipolar affective disorder: sampling, assessment, and analytic considerations. Psychiatr. Genet. 4, 43-55

57. First, M. B., Donovan, S., and Frances, A. (1996) Nosology of chronic mood disorders. Psychiatr. Clin. North Am. 19, 29-39

58. Fan, J. B., Chee, M. S., and Gunderson, K. L. (2006) Highly parallel genomic assays. Nat. Rev. Genet. 7, 632-644

59. Steemers, F. J., and Gunderson, K. L. (2007) Whole genome genotyping technologies on the BeadArray platform. Biotechnol. J. 2, 41-49

60. Purcell, S., Neale, B., Todd-Brown, K., Thomas, L., Ferreira, M. A., Bender, D., Maller, J., Sklar, P., De Bakker, P. I., Daly, M. J., and Sham, P. C. (2007) PLINK: a tool set for wholegenome association and population-based linkage analyses. Am. J. Hum. Genet. 81, 559-575

61. Weir, B. S. (1996) Genetic Data Analysis II. Sinauer Associates, Sunderland, MA, USA

62. Wittke-Thompson, J. K., Pluzhnikov, A., and Cox, N. J. (2005) Rational inferences about departures from Hardy-Weinberg equilibrium. Am. J. Hum. Genet. 76, 967-986

63. Wigginton, J. E., Cutler, D. J., and Abecasis, G. R. (2005) A note on exact tests of Hardy-Weinberg equilibrium. Am. J. Hum. Genet. 76, 887-893

64. Barrett, J. C., Fry, B., Maller, J., and Daly, M. J. (2005) Haploview: analysis and visualization of LD and haplotype maps. Bioinformatics 21, 263-265

65. Wang, N., Akey. J. M., Zhang, K., Chakraborty, R., and Jin, L. (2002) Distribution of recombination crossovers and the origin of haplotype blocks: the interplay of population history, recombination, and mutation. Am. J. Hum. Genet. 71, 1227-1234

66. Purcell, S., Cherny, S. S., and Sham, P. C. (2003) Genetic power calculator: design of linkage and association genetic mapping studies of complex traits. Bioinformatics 19, 149-150

67. Lange, C., DeMeo, D., Silverman, E. K., Weiss, S. T., and Laird, N. M. (2004) PBAT: tools for family-based association studies. Am. J. Hum. Genet. 74, 367-369

68. Steen, K. V., and Lange, C. (2005) PBAT: A comprehensive software package for genome-wide association analysis of complex family-based studies. Hum. Genomics 2, 67-69

69. Ewens, W. J., and Spielman, R. S. (1995) The transmission/ disequilibrium test: history, subdivision, and admixture. Am. J. Hum. Genet. 57, 455-464

70. Benjamini, Y., and Hochberg, Y. (1995) Controlling the false discovery rate: a practical and powerful approach to multiple testing. J. R. Stat. Soc. 57, 289-300

71. Storey, J. G., and Tibshirani, R. (2003) Statistical significance for genomewide studies. Proc. Natl. Acad. Sci. U. S. A. 100, 9440-9445

72. Jensen, L. J., Kuhn, M., Stark, M., Chaffron, S., Creevey, C., Muller, J., Doerks, T., Julien, P., Roth, A., Simonovic, M., Bork, P., and von Mering, C. (2009) STRING 8: a global view on proteins and their functional interactions in 630 organisms. Nucleic Acids Res. 37, 412-416

73. Mantel, N., and Haenszel, W. (1959) Statistical aspects of the analysis of data from retrospective studies of disease. J. Natl. Cancer Inst. 22, 719-748

74. Lohmueller, K. E., Pearce, C. L., Pike, M., Lander, E. S., and Hirschhorn, J. N. (2003) Meta-analysis of genetic association studies supports a contribution of common variants to susceptibility to common disease. Nat. Genet. 33, 177-182

75. Griffiths, R. C., and Tavare, S. (1994) Sampling theory for neutral alleles in a varying environment. Philos. Trans. $R$. Soc. Lond. B Biol. Sci. 344, 403-410

76. Griffiths, R. C., and Tavare, S. (1995) Unrooted genealogical tree probabilities in the infinitely-many-sites model. Math. Biosci. 127, 77-98

77. Tajima, F. (1989) Statistical method for testing the neutral mutation hypothesis by DNA polymorphism. Genetics 123, 585-595

78. Fu, Y. X., and Li, W. H. (1993) Statistical tests of neutrality of mutations. Genetics 133, 693-709

79. Watterson, G. A. (1978) The homozygosity test of neutrality. Genetics 88, 405-417

80. Nei, M., and Li, W. H. (1979) Mathematical model for studying genetic variation in terms of restriction endonucleases. Proc. Natl. Acad. Sci. U. S. A. 76, 5269-5273 
81. Fay, J. C., and Wu, C. I. (2000) Hitchhiking under positive Darwinian selection. Genetics 155, 1405-1413

82. Thornton, K. (2003) Libsequence: a C ++ class library for evolutionary genetic analysis. Bioinformatics 19, 2325-2327

83. Schaffner, S. F., Foo, C., Gabriel, S., Reich, D., Daly, M. J., Altshuler, D. (2005) Calibrating a coalescent simulation of human genome sequence variation. Genome Res. 15, 1576-1583

84. Excoffier, L., Laval, G., and Schneider, S. (2005) Arlequin ver. 3.0: An integrated software package for population genetics data analysis. Evol. Bioinform. Online 1, 47-50

85. Wright, S. I., and Charlesworth, B. (2004) The HKA test revisited: a maximum-likelihood-ratio test of the standard neutral model. Genetics 168, 1071-1076

86. Fumagalli, M., Cagliani, R., Pozzoli, U., Riva, S., and Comi, G. P. (2009) Widespread balancing selection and pathogen-driven selection at blood group antigen genes. Genome Res. 19, 199-212

87. Bandelt, H. J., Forster, P., and Röhl, A. (1999) Median-joining networks for inferring intraspecific phylogenies. Mol. Biol. Evol. 16, 37-48

88. Nielsen, R., Hellmann, I., Hubisz, M., Bustamante, C., and Clark, A. G. (2007) Recent and ongoing selection in the human genome. Nat. Rev. Genet. 8, 857-868

89. Jensen, J. D., Thornton, K. R., and Aquadro, C. F. (2008) Inferring selection in partially sequenced regions. Mol. Biol. Evol. 25, 438-446

90. Watterson, G. A. (1975) On the number of segregating sites in genetical models without recombination. Theor. Popul. Biol. 7, $256-276$

91. Hudson, R. R., Kreitman, M., and Aguade, M. (1987) A test of neutral molecular evolution based on nucleotide data. Genetics 116, 153-159

92. Hirayasu, Y. (2007) Brain imaging in schizophrenia. Neuropathology 27, 601-603

93. White, T., Cullen, K., Rohrer, L. M., Karatekin, C., Luciana, M., Schmidt, M., Hongwanishkul, D., Kumra, S., Schulz, S. C., and Lim, K. O. (2008) Limbic structures and networks in children and adolescents with schizophrenia. Schizophr. Bull. 34, 18-29

94. Parisi, M. A., Doherty, D., Chance, P. F., and Glass, I. A. (2007) Joubert syndrome (and related disorders) (OMIM 213300). Eur. J. Hum. Genet. 15, 511-521

95. Spampinato, M. V., Kraas, J., Maria, B. L., Walton, Z. J., and Rumboldt, Z. (2008) Absence of decussation of the superior cerebellar peduncles in patients with Joubert syndrome. Am. J. Med. Genet. 146A, 1389-1394

96. Doering, J. E., Kane, K., Hsiao, Y. C., Yao, C., Shi, B., Slowik, A. D., Dhagat, B., Scott, D. D., Ault, J. G., Page-McCaw, P. S., and Ferland, R. J. (2008) Species differences in the expression of Ahil, a protein implicated in the neurodevelopmental disorder Joubert syndrome, with preferential accumulation to stigmoid bodies. J. Comp. Neurol. 511, 238-256

97. Shinoda, K., Nagano, M., and Osawa, Y. (1993) An aromataseassociated cytoplasmic inclusion, the "stigmoid body," in the rat brain: II. Ultrastructure (with a review of its history and nomenclature). J. Comp. Neurol. 329, 1-19

98. Ockleford, C. D., Nevard, C. H., Indans, I., and Jones, C. J. (1987) Structure and function of the nematosome. J. Cell Sci. 87, $27-44$

99. Lisman, J. E., Coyle, J. T., Green, R. W., Javitt, D. C., Benes, F. M., Heckers, S., and Grace, A, A. (2008) Circuit-based framework for understanding neurotransmitter and risk gene interactions in schizophrenia. Trends Neurosci. 31, 234-242

100. Sheng, G., Xu, X., Lin, Y. F., Wang, C. E., Rong, J., Cheng, D., Peng, J., Jiang, X., Li, S. H., and Li, X. J. (2008) Huntingtinassociated protein 1 interacts with Ahil to regulate cerebellar and brainstem development in mice. J. Clin. Invest. 118, 2785-2795

101. Durany, N., Michel, T., Zochling, R., Boissl, K. W., CruzSanchez, F. F., Riederer, P., and Thome, J. (2001) Brainderived neurotrophic factor and neurotrophin 3 in schizophrenic psychoses. Schizophr. Res. 52, 79-86

102. Muglia, P., Vicente, A. M., Verga, M., King, N., Macciardi, F., and Kennedy, J. L. (2003) Association between the BDNF gene and schizophrenia. Mol. Psychiatry 8, 146-147

103. Gorsky, J. A., Zeiler, S. R., Tamowski, S., and Jones, K. R. (2003) Brain-derived neurotrophic factor is required for the maintenance of cortical dendrites. J. Neurosci. 23, 6856-6865
104. Hashimoto, T., Bergen, S. E., Nguyen, Q. L., Xu, B., Monteggia, L. M., Pierri, J. N., Sun, Z., Sampson, A. R., and Lewis, D. A. (2005) Relationship of brain-derived neurotrophic factor and its receptor TrkB to altered inhibitory prefrontal circuitry in schizophrenia. J. Neurosci. 25, 372-383

105. Jiang, X., Hanna, Z., Kaouass, M., Girard, L., and Jolicoeur, P. (2002) Ahi-1, a novel gene encoding a modular protein with WD40-repeat and SH3 domains, is targeted by the Ahi-1 and Mis-2 provirus integrations. J. Virol. 76, 9046-9059

106. Weinberger, D. R. (1987) Implications of normal brain development for the pathogenesis of schizophrenia. Arch. Gen. Psychiatry 44, 660-669

107. Sasaki, T., Kotera, J., Yuasa, K., and Omori, K. (2000) Identification of human PDE7B, a cAMP-specific phosphodiesterase. Biochem. Biophys. Res. Commun. 271, 575-583

108. Pérez-Torres, S., Cortés, R., Tolnay, M., Probst, A., Palacios, J. M., and Mengod, G. (2003) Alterations on phosphodiesterase type 7 and 8 isozyme mRNA expression in Alzheimer's disease brains examined by in situ hybridization. Exp. Neurol. 182, 322-334

109. Masson, D., and Kreis, T. E. (1993) Identification and molecular characterization of E-MAP-115, a novel microtubule-associated protein predominantly expressed in epithelial cells. J. Cell Biol. 123, 357-371

110. Morris, J. A., Kandpal, G., Ma, L., and Austin, C. P. (2003) DISC1 (Disrupted-In-Schizophrenia 1) is a centrosome-associated protein that interacts with MAP1A, MIPT3, ATF4/5 and NUDEL: regulation and loss of interaction with mutation. Hum. Mol. Genet. 12, 1591-1608

111. Bosc, C., Andrieux, A., and Job, D. (2003) STOP proteins. Biochemistry 42, 12125-12132

112. Andrieux, A., Salin, P. A., Vernet, M., Kujala, P., Baratier, J. Gory-Fauré, S., Bosc, C., Pointu, H., Proietto, D., Schweitzer, A., Denarier, E., Klumperman, J., and Job, D. (2002) defects associated with neuroleptic-sensitive behavioral disorders. Genes Dev. Sep. 15, 2350-2364

113. Frantseva, M. V., Fitzgerald, P. B., Chen, R., Möller, B., Daigle, M., and Daskalakis, Z. J. (2008) Evidence for impaired longterm potentiation in schizophrenia and its relationship to motor skill learning. Cereb. Cortex 18, 990-996

114. Huxley, J., Mayr, E., Osmond, H., and Hoffer, A. (1964) Schizophrenia as a genetic morphism. Nature 17, 220-221

115. Crow, T. J. (1997) Is schizophrenia the price that homo sapiens pays for language? Schizophr. Res. 9, 127-141

116. Keller, M. C., and Miller, G. (2006) Resolving the paradox of common, harmful, heritable mental disorders: which evolutionary genetic models work best? Behav. Brain Sci. 29, 385-404

117. Crow, T. J. (2008) The "big bang" theory of the origin of psychosis and the faculty of language. Schizophr. Res. 102, 31-52

118. Horrobin, D. F. (1998) Schizophrenia: the illness that made us human. Med. Hypotheses 50, 269-288

119. Khaitovich, P., Lockstone, H. E., Wayland, M. T., Tsang, T. M., Jayatilaka, S. D., Guo, A. J., Zhou, J., Somel, M., Harris, L. W. Holmes, E., Pääbo, S., and Bahn, S. (2008) Metabolic changes in schizophrenia and human brain evolution. Genome Biol. 9, R124

120. Zeng, K., Mano, S., Shi, S., and Wu, C. I. (2007) Comparisons of site- and haplotype-frequency methods for detecting positive selection. Mol. Biol. Evol. 24, 1562-1574

121. Zhai, W., Nielsen, R., and Slatkin, M. (2009) An investigation of the statistical power of neutrality tests based on comparative and population genetic data. Mol. Biol. Evol. 26, 273-283

122. Carrera, N., Sanjuán, J., Moltó, M. D., Carracedo, A., and Costas, J. (2009) Recent adaptive selection at MAOB and ancestral susceptibility to schizophrenia. Am. J. Med. Genet. B Neuropsychiatr. Genet. 150, 369-374

123. Wang, E., Ding, Y. C., Flodman, P., Kidd, J. R., Kidd, K. K., Grady, D. L., Ryder, O. A., Spence, M. A., Swanson, J. M., and Moyzis, R. K. (2004) The genetic architecture of selection at the human dopamine receptor D4 (DRD4) gene locus. Am. J. Hum. Genet. 74, 931-944

124. Langlois, M. R., and Delanghe, J. R. (1996) Biological and clinical significance of haptoglobin polymorphism in humans. Clin. Chem. 42, 1589-1600

Received for publication January 13, 2010. Accepted for publication March 18, 2010. 